\title{
Collatz Konjektürü'nün Bilgisayar Programı ile Hesaplanmasında Parite Sekansı Yöntemi Yaklaşımı
}

\section{The Parity Sequence Method Approach in Computing Collatz Conjecture via a Computer Program}

\author{
Mert Özkenar ${ }^{1}$ (i)
}

'İstanbul Aydın Üniversitesi, Bilgisayar Mühendisliği, İstanbul, Türkiye

ORCID: M.Ö. 0000-0003-4480-3991

Corresponding author:

Mert OZKENAR

İstanbul Aydın Üniversitesi, Bilgisaya

Mühendisliği, İstanbul, Türkiye

E-mail address: mertozkenar@stu.aydin.edu.tr

Submitted: 19.12 .2020

Revision Requested: 23.12 .2020

Last Revision Received: 24.12 .2020

Accepted: 24.12 .2020

Citation: Özkenar, M. (2020). Collatz Konjektürü'nün bilgisayar programı ile hesaplanmasında parite sekansı yöntemi yaklaşımı. Acta Infologica, 4(2), 97-121. https://doi.org/10.26650/acin.843275
ÖZ

Bu makalede, collatz konjektürü'nün bilgisayar programı ile hesaplamasında parite sekansı yöntemi yaklaşımı anlatılmıştır. Collatz konjektürüne dair kapsamlı araştırmalar ve çalışmalar yapılmış, tüm bilgilerin makalede yer alması amaçlanmıştır. Collatz konjektürünün hesaplanmasında kullanılacak olan parite sekansı yöntemi üzerinde çalışılmıştır. Yöntem için metodoloji oluşturulmuş, bilgisayar programları geliştirilmiş, sonuçlar bilgisayar çıktıları ve çıktılardan oluşan tablolar olarak paylaşılmış ve grafikler ile zenginleştirilmiştir. Collatz konjektürünün hesaplanmasına yönelik standart yöntemler karşılaştırılmış ve yöntem önerisinde bulunulmuştur. Üzerinde çalışılan yöntemlerin bilgisayar programları sayesinde etkinliği ve performansları ölçümlenmiştir. Önerilen yöntemin standart yönteme oranla daha başarılı olduğu yönünde bulgulara ulaşılmıştır. Tüm çalışmalara ayrıntılı olarak makale içerisinde yer verilmiştir. Makale çalışmasınında elde edilen yöntem özet değerleri ve karşılaştırma bilgileri, sonuç kısmında paylaşılmıştır. Anahtar kelimeler: Collatz Konjektürü, Bilgisayar Hesaplamalı Yöntemler, Parite Sekansı Yöntemi, Lothar Collatz, Dolu Taneleri Problemi

\section{ABSTRACT}

In this article, the parity sequence method approach for calculating the Collatz conjecture with a computer program is explained. Extensive research and studies have been conducted on the Collatz conjecture, and all the information obtained as a result of research and studies is intended to be included in the article. The parity sequence method, which will be used to calculate the Collatz conjecture, has been studied. A methodology was created for the method, computer programs were developed, the results were shared in tables consisting of computer outputs and enriched with graphics. Standard methods for calculating the Collatz conjecture were compared and a method was suggested. The efficiency and performance of the methods studied were measured by means of computer programs. It has been found that the proposed method is more successful than the standard method. All studies conducted on the Collatz conjecture and key findings are included in the article in detail. Method summary values and comparison information obtained in the article study are shared in the conclusion.

Keywords: Collatz Conjecture, Computer Computational Methods, Parity Sequence Method, Lothar Collatz, Hailstone Sequence 


\section{GİRIŞ}

Makalede Collatz Konjektürü’nün Bilgisayar Programı ile Hesaplanmasında Parite Sekansı Yöntemi Yaklaşımı konu edilmiştir. Collatz Konjektürü’nün hesaplanması için parite sekansı yöntemi üzerinde çalışılacak, yöntem önerisi sunulacak ve önerinin sağladığı fayda bilimsel kanıtlar ile ispat edilecektir.

Makalenin amaçlarından kısaca bahsetmek gerekirse; Collatz Konjektürü’nün yapısını, özelliklerini, işleyiş mekanizmasını tüm yönleriyle inceleyip üzerinde geliştirme çalışmaları yapmaktır. Collatz Konjektürü’nün hesaplanması için yöntemler belirlenecek, yöntemler arasında karşılaştırmalar yapılacak ve yöntem önerisinde bulunulacaktır. Sürecin içerisinde oluşturulan metodolojiye uygun bilgisayar programı geliştirmeleri yapılacak, sonuç kümeleri tablolar halinde paylaşılacak, grafik ve görseller ile konu pekiştirilecektir.

Makale çalışması süresince çok sayıda yerli ve yabancı kaynak incelenmiştir. Özel erişımli kütüphane veritabanları içerisinde araştırmalar yapılmıştır. Springer, IEEE, Web of Science, ScienceDirect, Times Higher Education başta olmak üzere internet kaynakları üzerinden literatür incelemeleri yapılmıştır. Uluslararası bilim, mühendislik ve matematik dergilerinde yayınlanan makaleler okunmuştır. Bazı konferans bildirilerine erişim sağlanmıştır. Yabancı üniversitelerin tez çalışmaları kontrol edilmiş, yerli tez çalışmalarına ise Ulusal Tez Merkezi aracılığıyla erişilmiştir. Kütüphane üzerinden de yayınlanan tezlere fiziksel olarak erişim firsatı bulunmuştur. Tüm kaynaklara ek olarak Academia ve ResearchGate üzerinde paylaşılan çalışmalar da okunarak makale çalışmasına katkıda bulunulmuştur.

Makale çalışmasının bir de Collatz Konjektürü özelinde hipotezi bulunmaktadır. Çalışmalar içerisinde yaklaşım önerisinde bulunulacaktır. Hipotez ise Collatz Konjektürü işlem hesaplamalarında parite sekansı yönteminin, standart yönteme göre hem toplam işlem adımı sayısı bazında hem de tüm işlemlerin tamamlanma süresi bazında daha başarılı olduğu tezidir.

Tez çalışması içerisinde "Collatz Konjektürü işlem hesaplamalarında parite sekansı yönteminin, standart yönteme göre hem toplam işlem adımı sayısı bazında hem de tüm işlemlerin tamamlanma süresi bazında daha iyi sonuçlar vermektedir." hipotezinin ispatı aranacak, oluşturulan metodolojiler temelinde geliştirilen bilgisayar programları sayesinde edinilen veriler ışı̆̆ında ispatı sağlanacaktır. Yine tüm çalışmalara ait veriler, çıktılar, grafikler ve görsellere detaylıca yer verilecektir. Çalışmalara, edinilen bilgilere ve varılan karara dair sonuç açıklaması da yapılacaktır.

\section{COLLATZ KONJEKTÜRÜ}

\subsection{Lothar Collatz}

Lothar Collatz, 6 Temmuz 1910’da Almanya'nın Vestfalya bölgesinde bulunan Arnsberg şehrinde doğdu. Stettin şehrinde büyüdü (Guenther, 1992). 1928'de Greifswald Üniversitesi’nde eğitime başladı (O’Connor \& Robertson, 2006). 1933‘e kadar Göttingen, Münih ve Berlin‘de okudu. Zamanın en önde gelen matematikçilerinden ve bilim adamlarından dersler aldı. 1933'te Staatsexamen'1 matematikte Richard von Mises ve fizikte Erwin Schrödinger’1n yönetiminde tamamladı. Siyasi iklim o sırada hızla değişiyordu ve Mises ile yapılan sınav esas olarak gelecekteki bir tez planlarını tartışmaktan ibaretti. Birkaç hafta sonra von Mises Almanya‘dan ayrıldı (Guenther, 1992). Lothar Collatz esasında von Mises‘ın danışmanlığgında olsa da 1935 yılında Berlin Üniversitesi'nde resmi olarak Alfred Klose ve Erhard Schmidt danışmanlığında doktorasını tamamladı (Guenther, 1992)(O’Connor \& Robertson, 2006). Habilitasyonunu Karlsruhe'de Theodor Pöschl ve Wilhelm Quade altında tamamlandı. Ardından 1935-1943 yılları arasında Karlsruhe‘deki Institut für Technische Mechanik‘te misafir öğretim görevlisi olarak ve Darmstadt'taki Institut für Praktische Mathematik'te çalıştı. 1943‘te Technische Hochschule Hannover‘de matematik profesörü oldu (Guenther, 1992). 1952‘de Hamburg Üniversitesi’ne geçti ve burada Uygulamalı Matematik Enstitüsü’nü kurdu (O’Connor \& Robertson, 2006). 1978‘de emekli oluncaya kadar burada kald1. Ölümüne kadar Hamburg'da fahri profesör olarak aktif kaldı ve burada araştırma yapmaya, öğretmeye, konferanslar düzenlemeye, seyahat etmeye, konuşmalar yapmaya ve matematiğin gelişimine katkıda bulunmaya devam etti. 1978‘den ölümüne kadar Aequationes Mathematicae de dahil olmak üzere çeşitli dergilerin editörlüğünü yaptı (Guenther, 1992). Kitapları ve akademik yayınlarının yanısıra, çalışmalarından dolayı çeşitli ödül ve nişanlara layık görüldü (O’Connor \& Robertson, 2006). 
Lothar Collatz kariyerini uygulamalı matematik alanına ve matematĭgin uygulanabilirlik aralı̆̆ını genişletmeye adadı. Matematiğin temel birliğine inanan biriydi ve bu nedenle araştırmasında daha geleneksel uygulamalı tekniklerin yanı sıra saf matematik alanlarını kullanma ve geliştirme konusunda hiçbir endişesi yoktu. İlk çalışmalarında sonlu fark yöntemleri ve özdeğer problemleri ile bunların teknik problemlere uygulanmasını ele aldı. Ayrıca kendi dahil etme teoremlerinin ilkini de kanıtladı. Bu teoremler ilk olarak literatürde Collatz Teoremi olarak anılsa da, kitaplarında hiçbir zaman onlardan bu şekilde bahsetmedi ve çalışmalarını yalnızca kitapları veya dersleri aracılığıyla bilenler pek çok güzel teoremin gerçekte onunla ilgili olduğunu asla anlayamayacaklardı. Hayatı boyunca teknik problemlere olan ilgisini sürdürdü ve amaçlarından biri modern matematiksel araştırmanın sonuçlarını uygulayıcı mühendis için erişilebilir kılmaktı. Araştırmaları ve alanının 1950'li yıllar civarında genel durumu Eigenwertaufgaben mit technischen Anwendungen, Akademische Verlagsgesellschaft ve Numerische Behandlung von Differentialgleichungen adlı kitaplarında özetlenmiştir (Guenther, 1992).

O sıralarda sayısal matematikteki son teknolojiden açıkça memnun değildi ve özellikle hata analizinde araştırmaya çok ihtiyaç duyulan alanlara işaret etti. Burada önemli katkılarda bulundu. Ellili ve altmışlı yılların başındaki çalışmaları, hata analizi, monotonluk yöntemleri, bir ve birkaç boyutta yaklaşım teorisi ve fonksiyonel analizin sayısal analize uygulamaları ile ilgiliydi. Bu sonuçların çoğu bugün hala kullanılmaktadır ve bunların birçoğu Funktionalanalysis und numerische Mathematik adlı iyi bilinen ve geniş çapta tercüme edilmiş kitabında bulunabilir. Lothar Collatz’n bir alanla ilgilenmeye başladığında, asla vazgeçmeyen bir yapısı vardı. Bu nedenle sonraki yıllarında araştırmasına yukarıdaki tüm alanlarda devam etti ve optimizasyon teorisi ile çatallanma teorisi gibi diğer alanlarda da çalışmalar yaptı (Guenther, 1992).

Matematikle birlikte iki tutkusu daha bulunmaktaydı. İlk olarak oyunları ve bulmacaları severdi.1955‘te oyunlar üzerine ilginç bir kurs verdi. Bu derste oyunları, yapılarını ve adaletlerini analiz etti. Oyunları kendisi icat etti. Ayrıca ifade edilmesi ve anlaşılması kolay, ancak çözülmesi oldukça zor olan Collatz Konjektürü’nü de ortaya koyan kişidir. Diğer tutkusu ise geometrik desenlerdi. Onları analiz etmek için kendi sistemini geliştirdi. İlk makalelerinden birinde, mutlak değerler aracılığıyla örtük olarak tanımlanan desenleri işlemiştir. Not ettiği yeni kalıpları araştırmaktan hoşlanıyordu. Materyallerinin bir kısmını sonraları yayınlamaya başlamıştı (Guenther, 1992).

Muazzam miktarda enerjisi vardı. Çok sayıda konferans verdi. Bu konferanslardan biri de kısa sürede bir olaya dönüşen Collatz Konjektürü konusundaydı. Hamburg`daki enstitüsünü fikir alışverişinde bulunan, birbirine sıkı sıkıya bağlı bir grup haline nasıl getireceğini bilen biriydi. Seyahatlerinde yeni fikirler aradı ve bunları dünya çapında arkadaşları ve meslektaşları ile paylaştı. Hayattan zevk alan, ilgi çekici ve sıcak bir kişiliğe sahipti ayrıca pek çok hobisi vardı. Sonuç olarak gittiği her yerde hoş bir misafirdi. Bir konferans veya geziden sonra fotoğraflarını ve eskizlerini arkadaşları ve katılımcılarıyla paylaşırdı (Guenther, 1992).

Profesör Lothar Collatz, 26 Eylül 1990‘da 80 yaşında iken Bulgaristan`ın Varna kentinde düzenlenen Bilgisayar Aritmetiği, Bilimsel Hesaplama ve Matematiksel Modelleme Uluslararası Sempozyumu'na katılımı esnasında öldü. Orada bir makale vermişti ve aktif bir katılımcıydı (Guenther, 1992)(O'Connor \& Robertson, 2006).

\subsection{Collatz Konjektürü}

\subsection{1 Ön bilgiler}

Lothar Collatz doktorasını tamamladıktan 2 y1l sonra 1937 yılında bir hipotez öne sürdü. Bu hipotez 20. yy’ın başlarından beri matematik çevrelerinde ve uluslararası alanda popüler oldu. Collatz’a göre: "Herhangi bir $n$ pozitif tam sayısından başlayarak $f(n)$ fonksiyonuna sokulan $n$ iterasyonları daima 1 rakamına ulaşır.". Fonksiyona verilen n sayısı tek ise sayı 3 ile çarpılır ve 1 eklenir, n sayısı çift ise sayı 2'ye bölünür. 1 rakamına ulaşana kadar iterasyon devam eder (Hammett, t.y.).

Hipotezin ispatı için çok sayıda çalışma yapıldı. Önemli matematikçiler uzun süreler boyunca üzerinde çalıştılar. Hipotezi ispatlayana Paul Erdős $\$ 500$, Bryan Thwaites $£ 1000$, Harold Scott MacDonald Coxeter $\$ 50$ ve karş1 örneğini bulup hipotezi çürütene ise $\$ 100$ para ödülü vaadinde bulunmuşlardır. Macar matematikçi Paul Erdős "Matematik bu tip problemler için henüz hazır değil.” ifadesini kullanmıştır (Lagarias, 2011). 


\subsubsection{Literatür Taraması}

Makale çalışması süresince giriş bölümünde detaylı bilgileri paylaşılan çok sayıda araştırma gerçekleştirilmiştir. Bununla birlikte çeşitli deneysel çalışmalar, gözlemler ve çıkarımlar yapılmıştır. Bu çalışmalara makaleyi oluşturan kısımlarında yer verilmiştir. Collatz Konjektürü konusunda geçmişten günümüze kadar çeşitli çalışmalar yapılmış, dergilerde makaleler yayımlanmış, konferanslar verilmiş, tezler yazılmış, özel enstitü ve üniversite araştırmaları yapılmıştır.

Bu başlıkta Collatz Konjektürü konusunda geçmişten bugüne kadar gerek Bilgisayar Mühendisliği ve Bilgisayar Bilimleri alanında, gerekse Matematik alanında mil taşı olarak nitelendirilebilecek çalışma özetleri paylaşılacaktır. Bu sayede Collatz Konjektürü’nün başlangıç noktasından gelinen noktaya kadar olan gelişimi konusunda genel bir görünüm oluşturulacaktır.

Muhtelif çalışma kaynaklarının yanı sıra, Jeffrey Clark Lagarias bu konuda oldukça önemli bir çalışmaya imza atmıştır. J. C. Lagarias 2011 yılında "The 3x+1 Problem: An Annotated Bibliography (1963-1999)" başlıklı bir çalışma yayımlamıştır. Çalışmasında Collatz Konjektürü’nün çıkış noktasından başlayarak adım adım gelinen noktanın bibliyografyasını çıkarmıştır. Çalı̧̧maların tarihçelerine, özet içeriklerine, yararlandığ çalışmalara ve sürecin ilerlemesinde katkıda bulunan çalışmalara ve makalelere de yer vermiştir.

Lothar Collatz ilk olarak 1937 yılında hipotezini öne sürmüştür. 1950'de ise International Math'e katılımı esnasında, informel bir konferansta $3 x+1$ problemini anlatmışıtır. Collatz Konjektürü ile ilgili bilinen ilk yayımlanan referans 1963 yılında Murray Seymour Klamkin'e ait olan "Problem 63-13*, An Infinite Permutation" isimli çalışmadır. Collatz Konjektürü hakkında dergide ilk yayımlanan çalışma ise 1971 yılında, Harold Scott MacDonald Coxeter'ın 1970 yılına ait ders notlarıdır. JeanPaul Allouche'un 1979 yılına ait "Sur la Conjecture de 'Syracuse-Kakutani-Collatz'" isimli çalışması ise Helmut Hasse tarafından önerilen formun genelleştirilmiş $3 x+1$ fonksiyonlarını incelemiştir. Brian Hayes, 1984 yılında "Computer Recreations: The Ups and Downs of Hailstone Numbers" isimli çalışmasında 3x+1 probleminden, "Dolu Taneleri Serisi" ismiyle bahsederek problemi bilinen diğer ismiyle tanıtmıştır. 1989 yılında ise H. Glaser and Hans-Georg Weigand'ın "DasULAM Problem-Computergestützte Entdeckungen" isimli makalesinde $3 x+1$ problemi Matematik ve Bilgisayar Bilimi arasında algoritmik bir problem olarak görülmektedir. Makalede problemin incelenmesinin matematiksel fikirlerin keşfinde eğitim kadar faydalı olduğu görüşü oluşmuştur. Araştırmada bir dizi soru formüle edilir ve bir kısmı yanıtlanır. Bunlardan bazıları Collatz fonksiyonunun belirli bir sayıdan başlayan ters yinelemeli ağaçlarının özellikleriyle ilgilidir. Makalede ayrıca $3 x+1$ problemi Pascal gibi programlama dilleri özelinde de tartışılmıştır. 1991 yılında Gaston Gonnet’a ait olan “Computations on the $3 x+1$ Conjecture" isimli makale, MAPLE kullanarak çok büyük n sayılarının $3 x+1$ fonksiyonu iterasyonlarını verimli bir şekilde hesaplamak için bilgisayar kodunun nasıl yazılacağını açıklamaktadır. David Applegate and Jeffrey C. Lagarias'ın 1995 y1lina ait "Density Bounds for the 3x+ 1 Problem I. Tree-Search Method" isimli makalesinde ise $3 x+1$ probleminin ağaç arama metodu özelinde yoğunluk sınırları üzerine çalışmaları paylaşılmıştır.

Collatz Konjektürü 1999 yılında Oliveira e Silva tarafından $2 \times 10^{16}$ 'ya kadar doğrulanmıştır. Daha sonrasında ise bu sayı Oliveira e Silva ve E. Roosendaal tarafından yapılan birbirinden bağımsız çalışmalarda $2 \times 10^{18}$ 'e ulaşmıştır (Lagarias, 2011). 2020 yılı itibariyle, bilgisayar tarafından doğrulanan başlangıç değerleri sayısı $2^{68} \approx 2.95 \times 10^{20}$ 'ye ulaşmıştır (Honner, 2020.).

Collatz Konjektürü hakkında son dönemde yapılan en önemli çalışma ise Terence Tao'ya aittir. Tao, 2019 yılında yayımladı̆̆g "Almost All Collatz Orbits Attain Almost Bounded Values" isimli makalesinde hemen hemen tüm Collatz yörüngelerinin sonsuzluğa ıraksayan herhangi bir fonksiyon ile sınırlı olduğunu olasılık kullanarak kanıtlamıştır (Tao, 2019).

\subsubsection{Problemin tanımı}

Tanım: Herhangi bir $n$ pozitif tam sayısından başlayarak $f(n)$ fonksiyonuna sokulan $n$ iterasyonları daima 1 rakamına ulaşır. Fonksiyona verilen $n$ sayısı tek ise sayı 3 ile çarpılır ve 1 eklenir, $n$ sayısı çift ise sayı 2'ye bölünür. 1 rakamına ulaşana kadar iterasyon devam eder (Hammett, t.y.).

Bu tanımda yer alan fonksiyon aşağıdaki gibi ifade edilmektedir; 
- $f: \mathbb{Z}^{+} \rightarrow \mathbb{Z}^{+}$

- $f_{0}=n, n \neq 0$

- $f_{i+1}=f_{i} / 2, f_{i}$ çift sayı ise

- $f_{i+1}=3 f_{i}+1, f_{i}$ tek sayı ise (Deloin, 2019).

\subsubsection{Collatz fonksiyonu}

Hipotez $n$ pozitif tam sayısının işleme girdiği $f(n)$ fonksiyonu detaylarına açıkça yer vermektedir. Bu fonksiyon matematiksel notasyonda aşağıdaki şekilde gösterilebilir;

$$
\begin{aligned}
C: \mathbb{Z}^{+} \rightarrow \mathbb{Z}^{+} \\
\begin{aligned}
C(n) & = \begin{cases}\frac{n}{2}, & n=>\mathrm{n} \% 2=0 \\
3 n+1, & n=>\mathrm{n} \% 2=1\end{cases} \\
F(n) & =\{n, C(n), C(C(n)), C(C(C(n))) \ldots\} \\
& =\left\{n, C(n), C^{2}(n), C^{3}(n) \ldots\right\} \quad \text { (Phillips, 2010). }
\end{aligned}
\end{aligned}
$$

Fonksiyona göre işleyiş mantı̆̆ aşağıdaki gibi özetlenebilir;

1. Herhangi bir $n$ pozitif tam sayısı seçilir.

2. Eğer $n$ sayısı çift ise $n$ 2'ye bölünür.

3. Eğer $n$ sayısı tek ise $n 3$ ile çarpılır ve 1 eklenir.

4. Fonksiyon sonucunda çıkan sayı l'e ulaşana kadar iterasyon devam eder (Davies, 2012).

\subsubsection{Konjektür notasyonu}

\section{Konjektür 1 (Collatz Konjektürü):}

Her $n \in \mathbb{Z}^{+}$için, $C^{k}(n)=1$ olan bir $k \in \mathbb{Z}^{+}$vardır.

$\forall n \in \mathbb{Z}^{+}, \ni C^{k}(n)=1 \quad k \in \mathbb{Z}^{+}$(Phillips, 2010).

Collatz Konjektürü’nün sade ve anlaşılır bir yapısı bulunmaktadır. Hipotezin tanımı, fonksiyonu ve özellikleri net olarak belirtilmiştir. Buradaki ispat bekleyen konu ise "Bu tanım tüm pozitif tam sayılara uygulandığında sonuç l'e ulaşır mı?" veya "Bu ifade tüm pozitif tam sayılar için doğru, geçerli midir?" sorusudur.

2020 yıl1 itibariyle, konjektür bilgisayar tarafından $2^{68} \approx 2.95 \times 10^{20}$ ye kadar olan tüm başlangıç değerleri için kontrol edilmiştir. Dolayısıyla karşı örnek arayan birisi yaklaşı 300 kentilyondan itibaren çalışmaya başlayabilir (Honner, 2020.).

$2^{68}$ e kadar tüm başlangıç değerleri kontrol edilmiş ve karşı bir örneğe rastlanmamıştır. Her defasında fonksiyona giren başlangıç değeri 1 rakamına ulaşarak varsayımı sağlamıştır. Bu nedenle Collatz Konjektürü; "Doğru olduğu düşünülen ancak doğruluğu henüz kanıtlanmamış veya reddedilmemiş matematiksel bir varsayımdır” (Santos, 2020.).

\subsubsection{Senaryolar ve realizasyonları}

Collatz Konjektürü'nün sayılar üzerindeki realizasyonlarına, fonksiyonun çalışma mantığına, fonksiyon iterasyonlarına ve işlem adım sayılarına örnekler üzerinden açıklama yapalım. Bununla birlikte çeşitli senaryoları inceleyelim. 
Öncelikle hesaplamanın yapılacağı fonksiyonu belirtelim;

$C: \mathbb{Z}^{+} \rightarrow \mathbb{Z}^{+}$

$$
C(n)= \begin{cases}\frac{n}{2}, & n \rightarrow n \equiv 0(\bmod 2) \\ 3 n+1, & n \rightarrow n \equiv 1(\bmod 2)\end{cases}
$$

Örneğin 5 rakamını fonksiyon üzerinden adım adım hesaplayalım;

1.5 tek sayı $\rightarrow 3 n+1$ işlemini uygula $\rightarrow$ sonuç 16

2. 16 çift sayı $\rightarrow n / 2$ işlemini uygula $\rightarrow$ sonuç 8

3. 8 çift sayı $\rightarrow n / 2$ işlemini uygula $\rightarrow$ sonuç 4

4. 4 çift sayı $\rightarrow n / 2$ işlemini uygula $\rightarrow$ sonuç 2

5.2 çift sayı $\rightarrow n / 2$ işlemini uygula $\rightarrow$ sonuç 1

1 (Fonksiyon iterasyonu 1 rakamına ulaştı, işlemi sonlandır.)

Bu örnekte seçilen 5 rakamı fonksiyon üzerinden işleme verildi. Toplamda 5 adımda 1 rakamına ulaştı.

Şimdi de 1'den 10'a kadar olan sayllar için hesaplanan serileri inceleyelim;

$$
\begin{aligned}
& C(1)=\{1\}, \\
& C(2)=\{2,1\}, \\
& C(3)=\{3,10,5,16,8,4,2,1\}, \\
& C(4)=\{4,2,1\}, \\
& C(5)=\{5,16,8,4,2,1\}, \\
& C(6)=\{6,3,10,5,16,8,4,2,1\}, \\
& C(7)=\{7,22,11,34,17,52,26,13,40,20,10,5,16,8,4,2,1\}, \\
& C(8)=\{8,4,2,1\}, \\
& C(9)=\{9,28,14,7,22,11,34,17,52,26,13,40,20,10,5,16,8,4,2,1\}, \\
& C(10)=\{10,5,16,8,4,2,1\}
\end{aligned}
$$

İncelenen örnekten de anlaşılacağı üzere Collatz Konjektürü’nde seride çıkan herhangi bir değerin tekrar kontrol edilmesine gerek bulunmamaktadır. Bir sonraki aşamada ise bu örnekteki $n$ sayılarını, oluşturdukları serileri, seride ulaştıkları maximum sayıları, 1 rakamına ulaşana kadar iterasyon işlemlerinin adım sayılarını, ulaştıkları sonuç değerlerinin tablosunu oluşturalım; 
Çizelge 2.1

Collatz Konjektürü'nde örnek olarak hesaplanan sayıların tablosu

\begin{tabular}{|c|c|c|c|c|}
\hline $\mathbf{n}$ & Seri & Max & i & Sonuç \\
\hline $1 *$ & - & - & - & 1 \\
\hline 2 & 2,1 & 2 & 1 & 1 \\
\hline 3 & $3,10,5,16,8,4,2,1$ & 16 & 7 & 1 \\
\hline 4 & $4,2,1$ & 4 & 2 & 1 \\
\hline 5 & $5,16,8,4,2,1$ & 16 & 5 & 1 \\
\hline 6 & $6,3,10,5,16,8,4,2,1$ & 16 & 8 & 1 \\
\hline 7 & $7,22,11,34,17,52,26,13,40,20,10,5,16,8,4,2,1$ & 52 & 16 & 1 \\
\hline 8 & $8,4,2,1$ & 8 & 3 & 1 \\
\hline 9 & $9,28,14,7,22,11,34,17,52,26,13,40,20,10,5,16,8,4,2,1$ & 52 & 19 & 1 \\
\hline 10 & $10,5,16,8,4,2,1$ & 16 & 6 & 1 \\
\hline
\end{tabular}

*1 rakamı fonksiyonda işleme girdiğinde $\{1,4,2,1,4,2 \ldots\}$ iterasyonu ile karşılaşı1ır.

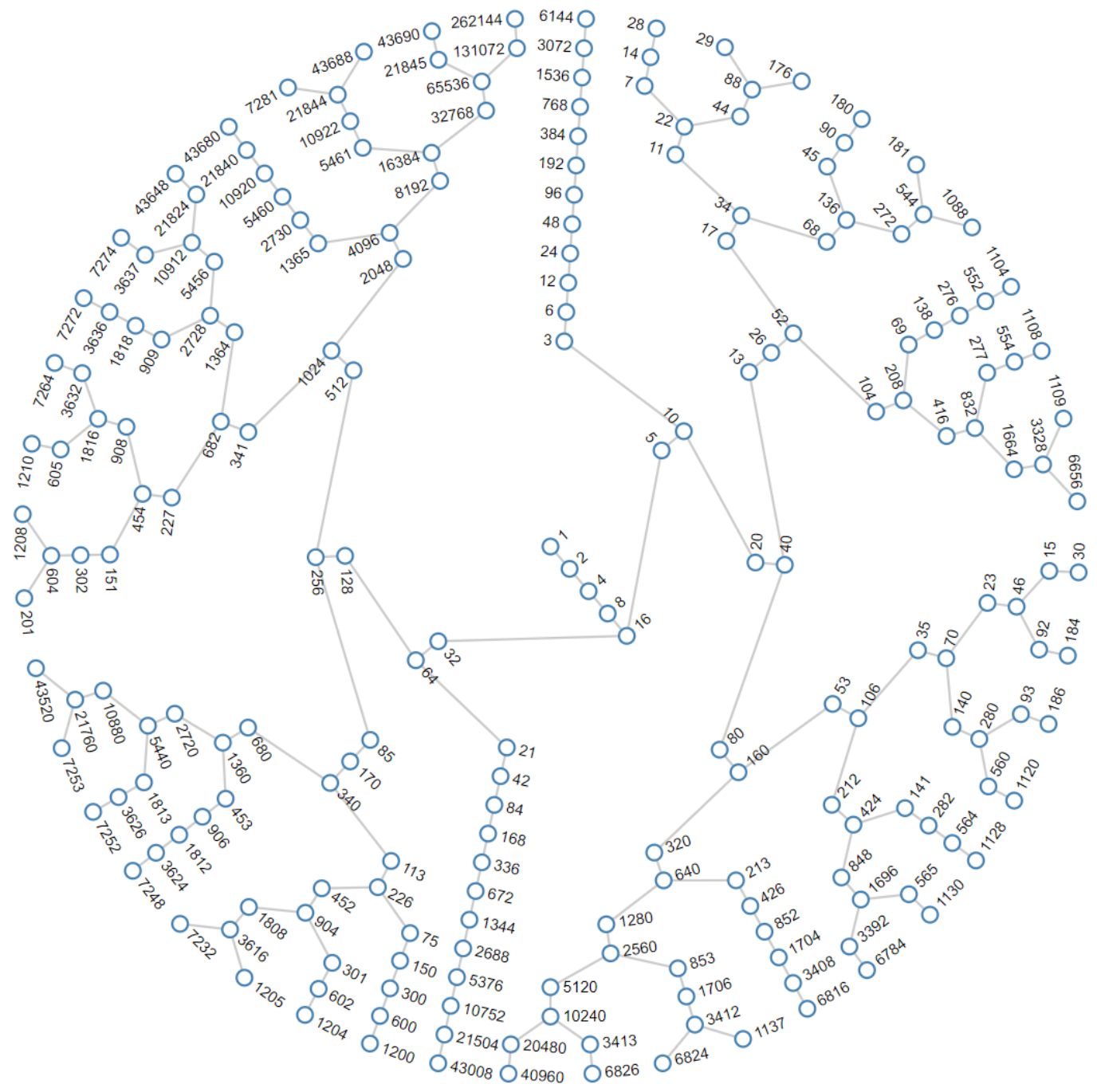

Şekil 2.1. Collatz Konjektürü’nde sayıların yörüngelerini gösteren harita grafiği (Davies, 2012).

Collatz Konjektürü hesaplanırken seride çıkan sayılar, başlangıç sayısı ve maksimum sayı arasındaki fark, başlangıç sayısına göre adım sayısının lineer olmaması gibi pek çok düzensizlik dikkat çekicidir. Kümülonimbus bulutu içerisindeki dolu taneleri yeryüzüne düşüne kadar gelişigüzel desenlerle aşağı ve yukarı sürüklenir. Bu benzetmeden yola çıkarak Collatz Konjektürü “Dolu Taneleri Sekansı” ya da “Dolu Taneleri Konjektürü” olarak da isimlendirilir (y.y., t.y.). 
İşlemler görselleştirildiğinde iniş̧li çıkışlı durumlar daha net belirmektedir. Belirli sayı aralıklarında hesaplama yaparken maksimum adım sayısına ulaşan bazı örnekler aşağıda paylaşılmıştır;

- 10'dan az 9 rakam 19 adımda,

- 100'den az 97 sayıs1 118 adimda,

- 1,000'den az 871 sayısı 178 adımda,

- 10,000 'den az 6,171 sayısı 261 adımda,

- 100,000'den az 77,031 sayıs1 350 adımda,

- 1 milyon'dan az 837,799 sayıs1 524 adımda,

- 10 milyon'dan az 8,400,511 sayısı 685 adımda,

- 100 milyon'dan az 63,728,127 sayıs1 949 adımda,

- 1 milyar'dan az 670,617,279 sayıs1 986 adımda,

- 10 milyar'dan az 9,780,657,630 sayısı 1132 adımda,

- 100 milyar'dan az 75,128,138,247 sayısı 1228 adımda,

- 1 trilyon'dan az 989,345,275,647 sayısı 1348 adımda,

- 10 trilyon'dan az 7,887,663,552,367 sayısı 1563 adımda,

- 100 trilyon'dan az 80,867,137,596,217 sayısı 1662 adımda,

- 1 katrilyon'dan az 942,488,749,153,153 sayıs1 1862 adımda,

- 10 katrilyon'dan az 7,579,309,213,675,935 sayısı 1958 adımda,

- 100 katrilyon'dan az 93,571,393,692,802,302 sayısı 2091 adımda.

hesaplanabilmektedir (y.y., t.y.).

Çizelge 2.2.

Belirli aralıklarda maksimum adım sayısına ulaşan örnekler tablosu

\begin{tabular}{lcccc}
\hline $\mathbf{n}$ & Başlangıç & Bitiş & Aralık & i \\
\hline 9 & $10^{0}$ & $10^{1}$ & $10^{0}<\mathrm{n}<10^{1}$ & 19 \\
\hline 97 & $10^{1}$ & $10^{2}$ & $10^{1}<\mathrm{n}<10^{2}$ & 118 \\
\hline 871 & $10^{2}$ & $10^{3}$ & $10^{2}<\mathrm{n}<10^{3}$ & $10^{3}<\mathrm{n}<10^{4}$ \\
\hline 6,171 & $10^{3}$ & $10^{4}$ & $10^{4}<\mathrm{n}<10^{5}$ & 261 \\
\hline 77,031 & $10^{4}$ & $10^{5}$ & $10^{5}<\mathrm{n}<10^{6}$ & 350 \\
\hline 837,799 & $10^{5}$ & $10^{6}$ & $10^{6}<\mathrm{n}<10^{7}$ & 524 \\
\hline $8,400,511$ & $10^{6}$ & $10^{7}$ & $10^{7}<\mathrm{n}<10^{8}$ & 685 \\
\hline $63,728,127$ & $10^{7}$ & $10^{8}$ & $10^{8}<\mathrm{n}<10^{9}$ & 949 \\
\hline $670,617,279$ & $10^{8}$ & $10^{\wedge 9}$ & $10^{9}<\mathrm{n}<10^{10}$ & 986 \\
\hline $9,780,657,630$ & $10^{9}$ & $10^{\wedge 10}$ & 1132 \\
\hline $75,128,138,247$ & $10^{10}$ & $10^{\wedge 11}$ & $10^{11}<\mathrm{n}<10^{11}$ & 1228 \\
\hline $989,345,275,647$ & $10^{11}$ & $10^{\wedge 12}$ & $10^{12}<\mathrm{n}<10^{13}$ & 1348 \\
\hline $7,887,663,552,367$ & $10^{12}$ & $10^{\wedge 13}$ & $10^{13}<\mathrm{n}<10^{14}$ & 1563 \\
\hline $80,867,137,596,217$ & $10^{13}$ & $10^{\wedge 14}$ & $10^{14}<\mathrm{n}<10^{15}$ & 1662 \\
\hline $942,488,749,153,153$ & $10^{14}$ & $10^{\wedge 15}$ & $10^{15}<\mathrm{n}<10^{16}$ & 1862 \\
\hline $7,579,309,213,675,935$ & $10^{15}$ & $10^{\wedge 16}$ & $10^{16}<\mathrm{n}<10^{17}$ & 1958 \\
\hline $93,571,393,692,802,302$ & $10^{16}$ & $10^{\wedge 17}$ & & 2091 \\
\hline
\end{tabular}




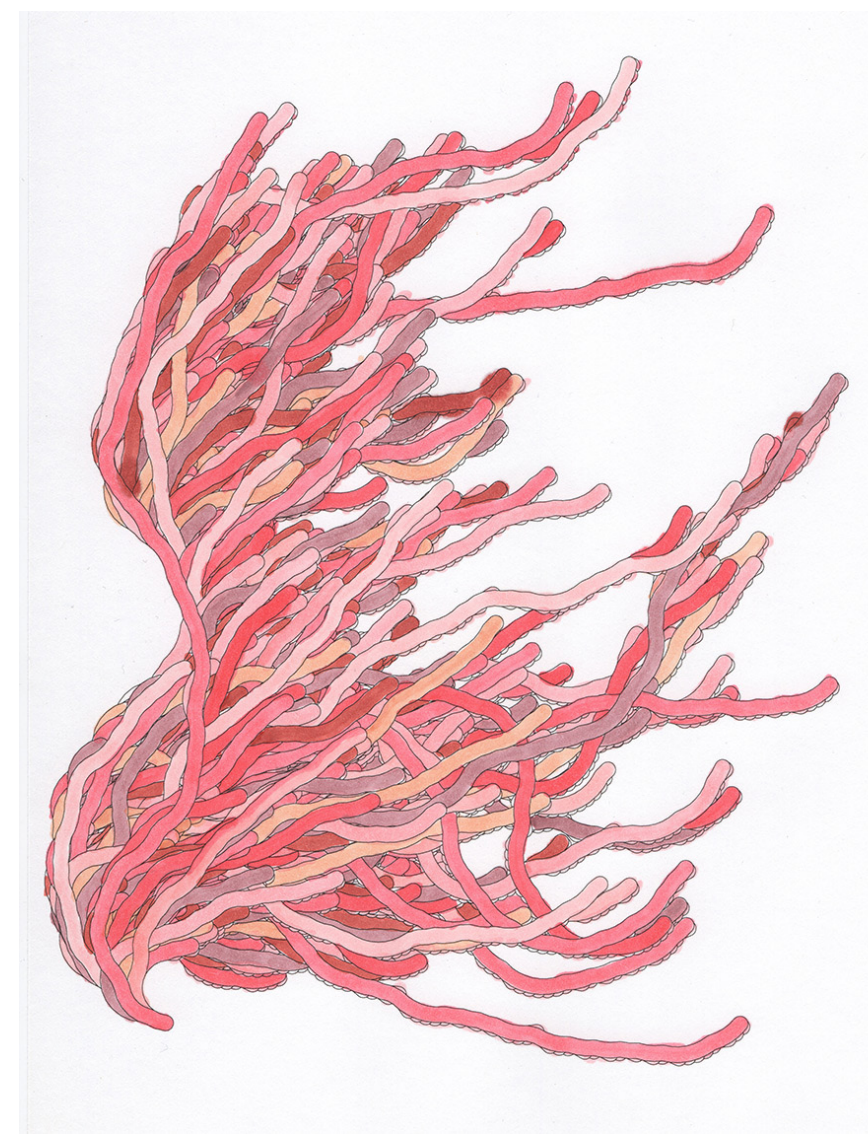

Şekil 2.2. Collatz Konjektürü’nün suda dalgalanan deniz yosunu illüstrasyonu (Haran., 2017).

Şekil 2.2'de yer alan illüstrasyon Alex Bellos ve Edmund Harriss'in Amerika Birleşik Devletleri'nde Visions of the Universe, Birleşik Krallık'ta ise Visions of Numberland ismiyle yayınlanan kitabından alıntıdır. Birçok farklı başlangıç noktasından oluşan sayıların tamamı bitkinin kökünde 1 rakamına ulaşmaktadır. Bitkinin köküne ulaşana kadar uçlar çok sayıda noktada aynı dallarda buluşmaktadır. Sayı dizisinde 1 rakamına ulaşırkan aynı seriyi takip eden sayılardan oluşmaktadırlar. İllüstrasyon bu yönleriyle Collatz Konjektürü’nü simgelemektedir.

Günümüzde Collatz Konjetürü’nün hesaplanmasına bilgisayarlar tarafından devam edilmektedir. California Üniversitesi’nde BOINC ve Science United projelerinin çalışmaları yürütülmektedir. Bu projeler Ulusal Bilim Vakfı tarafından desteklenmektedir. BOINC programı, bilgisayarınızı kullanarak en son bilim araştırmalarına yardımcı olmanızı sağlar. Programı bilgisayarınıza indirip, kurmanız yeterlidir. Bilgisayarınızda çalışan BOINC uygulaması, bilimsel hesaplama işlerini indirir ve bunları arka planda görünmez bir şekilde çalıştıır. Yaklaşı 30 bilim projesi BOINC programını kullanmaktadır (y.y.., 2020). Collatz Konjektürü de bu bilimsel araştırma projelerinden birisidir. İnternete bağlı bilgisayarlar tarafından Collatz Konjektürü’nün matematik araştırmaları ve hesaplamaları yapılmaktadır. BOINC projelerinin bir kısmı Berkeley'de yer alırken, Collatz Konjektürü ise Illinois'de yerleşiktir. Özel olarak yönetilen bu BOINC projesinin temel amacı Collatz Konjektürü’nü çürütmektir. Collatz Konjektürü projesi eşlik dizisi optimizasyonunu kullanır. Program işletim sistemi üzerinde çalışır, CPU ve grafik kartlarını kullanır (Sonntag, 2020).

Proje kapsamında; proje sunucularının durumu, hesaplama statüleri altında gönderime hazır olan, işlemi devam eden, silinmesi beklenen task adetleri, validasyon bekleyen, asimilasyon bekleyen, silinmesi beklenen iş birimi adetleri, saat bazında iş yığını geçişlerinin yanısıra bilgisayar ve kullanıcı adetleri, son 24 saat içerisinde kaydı gerçekleşmiş olanların adetleri ile Collatz Sieve uygulamasına ait task adetleri gibi bilgiler paylaşılmaktadır. Liderlik tablosu altında zirvedeki katılımcılar, takımlar ve bilgisayarların bilgilerini içeren listeler yer almaktadır. En iyi CPU performansları ile en prodaktif GPU modelleri de listelenmektedir. 
Projeye ait web sayfasında önemli istatistiksel bilgiler de bulunmaktadır. Bunlardan biri Collatz Konjektürü hesaplamarında, maksimum adım sayısına göre bugüne kadar alınan en iyi sonuçlardır. Güncel bilgi esas alındığında listenin birinci sırasında 2,968 adımla 7,219,136,416,377,236,271,195 sayısı bulunmaktadır (y.y. , 2020). Diğger önemli istatistiksel bilgi ise ulaşılan en yüksek sayıdır. Günlük olarak, günün en yüksek sayısı 1 rakamına ulaşılabildiği adım sayısı ile listelenir. Yine güncel bilgi esas alındığında listenin birinci sırasında 2516 adımla 9,033,093,293,652,500,451,647 sayısı bulunmaktadır (y.y. , 2020).

\subsection{6 İterasyonlar}

Collatz Konjektürü’nde sayıların hesaplama işlemleri, konjektürün tanımlı olan fonksiyonu sayesinde yapılmaktadır. Fonksiyona giren sayı işlemler sonucunda 1 rakamına ulaşana kadar iterasyon devam eder. Bu bölümde bilenen iterasyonlar ile farklı uygulama türleri incelenecektir.

İlk olarak Collatz Konjektürü’nde hesaplanmak üzere pozitif tam sayılar kümesinden 1 rakamı seçilirse;

$C: \mathbb{Z}^{+} \rightarrow \mathbb{Z}^{+}$

$C(n)= \begin{cases}\frac{n}{2}, & n \rightarrow n \equiv 0(\bmod 2) \\ 3 n+1, & n \rightarrow n \equiv 1(\bmod 2)\end{cases}$

1. 1 tek sayı $\rightarrow 3(1)+1$ işlemini uygula $\rightarrow$ sonuç 4

2. 4 çift sayı $\rightarrow 4 / 2$ işlemini uygula $\rightarrow$ sonuç 2

3. 2 çift sayı $\rightarrow 2 / 2$ işlemini uygula $\rightarrow$ sonuç 1

4. 1 tek sayı $\rightarrow 3(1)+1$ işlemini uygula $\rightarrow$ sonuç 4

5. 4 çift sayı $\rightarrow 4 / 2$ işlemini uygula $\rightarrow$ sonuç 2

6. 2 çift sayı $\rightarrow 2 / 2$ işlemini uygula $\rightarrow$ sonuç 1

$\mathrm{C}(1)=\{1,4,2,1,4,2 \ldots\}$

Bu senaryoda 1,4 ,2 1,4,2... iterasyonu ile karşılaşılır. İterasyon sonsuza kadar devam eder, sonuç kümesi ise sonsuza gider.

Aynı senaryo ile 1 rakamından farklı verilen pozitif tam sayının, işlemler sonucunda 1 rakamına ulaşana kadar iterasyonun devam etmesine rağmen 1 rakamında iterasyonun devam ettirilmesi ile de karşılaşılabilir;

1. 10 çift sayı $\rightarrow 10 / 2$ işlemini uygula $\rightarrow$ sonuç 5

2.5 tek sayı $\rightarrow 3(5)+1$ işlemini uygula $\rightarrow$ sonuç 16

3. 16 çift sayı $\rightarrow 16 / 2$ işlemini uygula $\rightarrow$ sonuç 8

4. 8 çift sayı $\rightarrow 8 / 2$ işlemini uygula $\rightarrow$ sonuç 4

5.4 çift sayı $\rightarrow 4 / 2$ işlemini uygula $\rightarrow$ sonuç 2

6. 2 çift sayı $\rightarrow 2 / 2$ işlemini uygula $\rightarrow$ sonuç 1

7. 1 tek say $\rightarrow 3(1)+1$ işlemini uygula $\rightarrow$ sonuç 4

8 . 4 çift sayı $\rightarrow 4 / 2$ işlemini uygula $\rightarrow$ sonuç 2

9. 2 çift sayı $\rightarrow 2 / 2$ işlemini uygula $\rightarrow$ sonuç 1

$C(10)=\{10,5,16,8,4,2,1,4,2 \ldots\}$ 
0 rakamı da farklı bir iterasyon oluşturmaktadır. Collatz Konjektürü sadece pozitif tam sayılar kümesinde yer alan sayıları incelemektedir. Collatz Konjektürü’nde hesaplanmak üzere doğal sayılar kümesinden 0 rakamı seçilirse;

$$
\mathrm{C}(0)=\{0 \ldots\}
$$

0 iterasyonu ile karşılaşılmaktadır.

Bir diğer senaryo ise aşağıda örnekleri yer alan negatif tam sayılar ile hesaplama yapılırken ortaya çıkmaktadır. Negatif tam sayılar kümesi içerisinde de iterasyon ile karşılaşılan sayılar bulunmaktadır. Collatz Konjektürü’nde hesaplanmak üzere negatif tam sayılar kümesinden -1 sayısı seçilirse;

$$
\begin{aligned}
& -1 \rightarrow-2 \rightarrow-1 \ldots \\
& C(-1)=\{-1,-2,-1 \ldots\}
\end{aligned}
$$

Collatz Konjektürü’nde hesaplanmak üzere negatif tam sayılar kümesinden -5 sayısı seçilirse;

$$
\begin{aligned}
& -5 \rightarrow-14 \rightarrow-7 \rightarrow-20 \rightarrow-10 \rightarrow-5 \ldots \\
& C(-5)=\{-5,-14,-7,-20,-10,-5 \ldots\}
\end{aligned}
$$

Son olarak Collatz Konjektürü’nde hesaplanmak üzere negatif tam sayılar kümesinden -17 sayısı seçilirse;

$$
\begin{aligned}
-17 \rightarrow-50 \rightarrow-25 \rightarrow-74 \rightarrow-37 \rightarrow-110 \rightarrow-55 \rightarrow-164 \\
\rightarrow-82 \rightarrow-41 \rightarrow-122 \rightarrow-61 \rightarrow-182 \rightarrow-91 \rightarrow-272 \rightarrow \\
-136 \rightarrow-68 \rightarrow-34 \rightarrow-17 \ldots \\
C(-17)=\{-1-17,-50,-25,-74,-37,-110,-55,-164,-82, \\
\quad-41,-122,-61,-182,-91,-272,-136,-68,-34,-17 \ldots \vdash\}
\end{aligned}
$$

iterasyonları ile karşılaşılmaktadır (Weisstein, t.y.).

\section{BÍLGISAYAR PROGRAMI GELİSTTIRMELERİ}

\subsection{Parite Sekansı Yöntemi}

Bu bölümde Collatz Konjektürü’nün parite sekansı yöntemi ile geliştirilen bilgisayar programı sayesinde hesaplanması incelenecektir. Parite sekansı yönteminde geliştirme çalışmaları Collatz Konjektürü’nün türetilmiş tanımı ve türetilmiş fonksiyonu üzerinden kurgulanmıştır.

Collatz Konjektürü’nün hesaplanması için bilim insanları ve bilgisayarlar tarafından uygulanan çeşitli yöntemler bulunmaktadır. Yöntemler tanımların ve fonksiyonların türetilmesi ile elde edilen farklı yaklaşımlardan oluşmaktadır. Her yöntem özelinde çeşitli faydalar ve kısıtlar bulunmaktadır. Örneğin soyut makina yönteminde özellikle iterasyondaki $n \rightarrow n \equiv 1$ (mod 2) koşulunu sağlayan $n$ sayıları üzerinde yoğunlaşılmıştır. Fonksiyonun işleyiş mekanizması binary (ikili) sayı sistemi üzerine kurgulanmıştır. Süreç boyunca da işlemler binary kodlar üzerinden devam eder ve tamamlanır. Fonksiyona verilen $n$ sayısı binary koda dönüştürülür. $n$ sayısı $n \rightarrow n \equiv 0(\bmod 2)$ koşulunu sağlıyor ise sayı sondaki 0 adedi kadar 2'ye bölünür. $n$ sayısı $n \rightarrow n \equiv 1(\bmod 2)$ koşulunu sağlıyor ise sayı 3 ile çarpılır ve 1 eklenir, bu işlem sonucunda elde edilen $n$ sayısı $n \rightarrow n \equiv 0$ $(\bmod 2)$ koşulunu sağlıyor ise sayı 2'ye bölünür. 1 rakamına ulaşana kadar iterasyon devam eder. Parite sekansı yönteminde ise günlük hayatta kullanılan 10’luk (decimal) sayı sistemi esas alınır.

Yöntemin faydaları ve kısıtları standart yöntem ile karşılaştırmalı olarak incelenmiştir. Öneride bulunulan yöntem özelinde detaylandırılmıştır. Bu faydalar aşağıda yer alan iki maddede, kısıtlar ise son kısımda açıklanmıştır ;

- Collatz Konjektürü işlem hesaplamalarında parite sekansı yöntemi, standart yönteme göre toplam işlem adımı sayısı bazında daha başarılıdır. Collatz Konjektürü’nün parite sekansı yöntemine özel türetilmiş tanımı ve türetilmiş 
fonksiyonu $n$ sayısının $n \rightarrow n \equiv 1(\bmod 2)$ koşulunu sağladığı her iterasyonda adım sayısını azaltmaktadır. Sayı bu koşulu sağlayarak iterasyona girdiğinde çıkan sonuç, $n \rightarrow n \equiv 0(\bmod 2)$ koşulunu sağlayarak tekrar iterasyona girmesine gerek bırakmadan 2' ye bölme işlemine tabi tutulur. Böylece diğer iterasyon adımı elenmiş olmaktadır. Fonksiyona giren $n$ sayısı 1 rakamına ulaştığında toplam serideki adım sayısının standart yönteme göre daha az olduğu ölçümlenebilmektedir. Bu durumun tek istisnasını ise serideki tüm sayıları $n \rightarrow n \equiv 0(\bmod 2)$ koşulunu sağlayan $n$ sayıları oluşturmaktadır.

- Collatz Konjektürü işlem hesaplamalarında parite sekansı yöntemi, standart yönteme göre tüm işlemlerin tamamlanma süresi bazında daha iyi sonuçlar vermektedir. Collatz Konjektürü’nün parite sekansı yöntemine özel türetilmiş tanımı ve türetilmiş fonksiyonu tüm işlemleri daha kısa sürede tamamlamaktadır. Fonksiyon yapısı gereği iterasyonda $n \rightarrow$ $n \equiv 1(\bmod 2)$ koşulunu sağlayan $n$ sayısını tekrar döngüye sokmaz. Hâlihazırdaki $n$ sayısının aritmetiksel modulo işlemine tabi tutulmasına gerek bırakmaz. Bu durum fonksiyona verilen $n$ sayısının tüm işlemlerinin daha kısa sürede tamamlanmasını mümkün kılar.

Yöntemin uygulanmasına yönelik herhangi bir kısıt ise bulunmamaktadır.

\subsubsection{Metodoloji}

\subsubsection{1 Önerme}

Önerme 1 (Collatz Konjektürü): Herhangi bir $n$ pozitif tam sayısından başlayarak $f(n)$ fonksiyonuna sokulan $n$ iterasyonları daima 1 rakamına ulaşır. Fonksiyona verilen $n$ sayısı tek ise sayı 3 ile çarpılır, 1 eklenir ve 2'ye bölünür, $n$ sayısı çift ise sayı 2’ye bölünür. 1 rakamına ulaşana kadar iterasyon devam eder (Hammett, t.y.).

$\mathrm{Bu}$ önermede yer alan fonksiyon aşağıdaki gibi ifade edilmektedir;

$$
\begin{aligned}
& f: \mathrm{Z}^{+} \rightarrow \mathrm{Z}^{+} \\
& f_{0}=\mathrm{n}, \mathrm{n} \neq 0 \\
& f_{\mathrm{i}+1}=f_{\mathrm{i}} / 2, f_{\mathrm{i}} \text { çift sayı ise } \\
& f_{\mathrm{i}+1}=\left(3 f_{\mathrm{i}}+1\right) / 2, f_{\mathrm{i}} \text { tek sayı ise }
\end{aligned}
$$

\subsubsection{Prosedür}

Collatz Konjektürü’nün parite sekansı yöntemine özel türetilmiş önermede yer alan fonksiyona göre işleyiş mantığı aşağıdaki gibi özetlenebilir;

1. Herhangi bir $n$ pozitif tam sayısı seçilir.

2. Eğer $n$ sayısı çift ise $n$ 2’ye bölünür.

3. Eğer $n$ sayısı tek ise $n 3$ ile çarpılır, 1 eklenir ve 2'ye bölünür.

4. Fonksiyon sonucunda çıkan sayı 1'e ulaşana kadar iterasyon devam eder.

\subsubsection{Notasyon}

Önermede ifade edilen fonksiyon parite sekansı yöntemine özel türetilmiştir. Standart yöntemde belirtilen orijinal fonksiyonun $C_{s}(n)$ ve parite yöntemine özel türetilmiş fonksiyonun $C_{p}(n)$ matematiksel notasyonda gösterimi aşağıdaki gibidir. Bilgisayar programında parite fonksiyonuna özel türetilmiş tanım ve türetilmiş fonksiyon esas alınacaktır. 
$C: \mathbb{Z}^{+} \rightarrow \mathbb{Z}^{+}$

$$
\begin{aligned}
& C_{s}(n)= \begin{cases}\frac{n}{2}, & n \rightarrow n \equiv 0(\bmod 2) \\
3 n+1, & n \rightarrow n \equiv 1(\bmod 2)\end{cases} \\
& C_{p}(n)= \begin{cases}\frac{n}{2}, & n \rightarrow n \equiv 0(\bmod 2) \\
\frac{3 n+1}{2}, & n \rightarrow n \equiv 1(\bmod 2)\end{cases}
\end{aligned}
$$

Tanımlanan fonksiyonda yer alan $3 n+1$ işlemi her zaman çift sayı sonucunu vereceği için, parite sekansı yönteminde tek sayılar için $(3 n+1)$ / 2 işlemi uygulanabilmektedir.

Şimdi de Collatz Konjetürü’nde 3 sayısını hem standart yöntem ile hem de parite sekansı yöntemiyle hesaplayalım. Her iki yöntem için de hesaplanan serileri inceleyelim;

$C_{s}(3)=\{3,10,5,16,8,4,2,1\}$

Bu örnekte seçilen 3 sayısı standart yöntem fonksiyonu üzerinden işleme verildi. Toplamda 7 adımda 1 rakamına ulaştı.

$C_{p}(3)=\{3,5,8,4,2,1\}$

Bu örnekte seçilen 3 sayısı parite sekansı yöntemi fonksiyonu üzerinden işleme verildi. Toplamda 5 adımda 1 rakamına ulaştı.

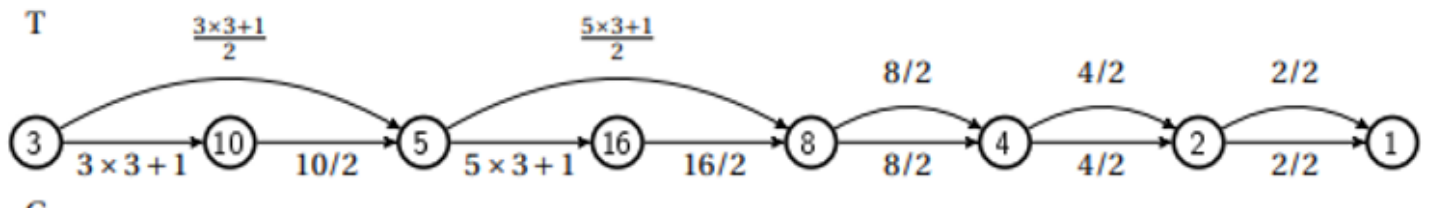

C

Şekil 3.1. Parite sekansı yöntemi hesaplama adımları gösterimi (Bairrington \& Okano, 2019).

\subsubsection{Bilgisayar programı ve program mimarisi}

\subsubsection{Algoritma}

Algoritma programlama terminolojisinde; bir problem sınıfını çözmek veya hesaplama yapmak için iyi tanımlanmış, bilgisayar tarafından işlenecek kural veya talimatlar dizisidir. Collatz Konjektürü’nde parite sekansı yöntemi ile işlemlerini yapacak olan programın algoritması aşağıdaki şekilde geliştirilmiştir;

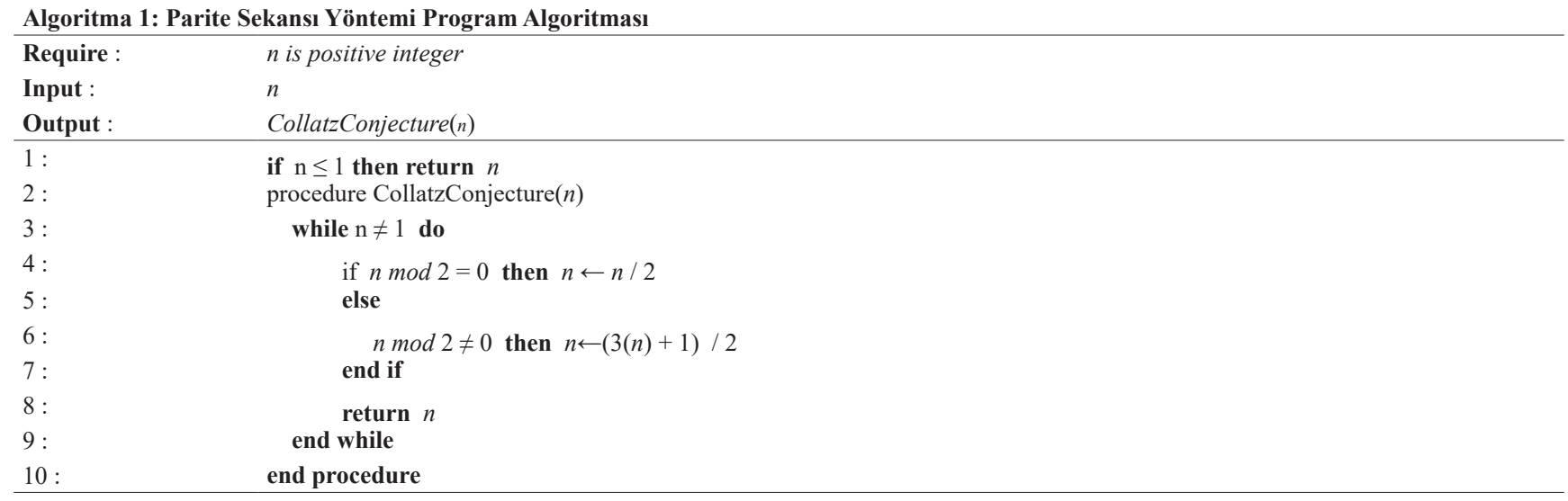




\subsubsection{Akış diyagramı}

Fonksiyonların çalışma mantığı ifade edilirken giriş değeri, fonksiyon ve çıkış değeri şeklinde gösterimi yapılmaktadır. Fonksiyon kısmında giriş değerinin hangi işlemlerden geçtiği, içerideki işleyiş mekanizması ve çıkış değeri oluşana kadar tüm süreç yer alır. Aşağıda Collatz Konjektürü’nde parite sekansı yöntemi ile işlemlerini yapacak olan program fonksiyonunun gösterimi yapılmıştır;

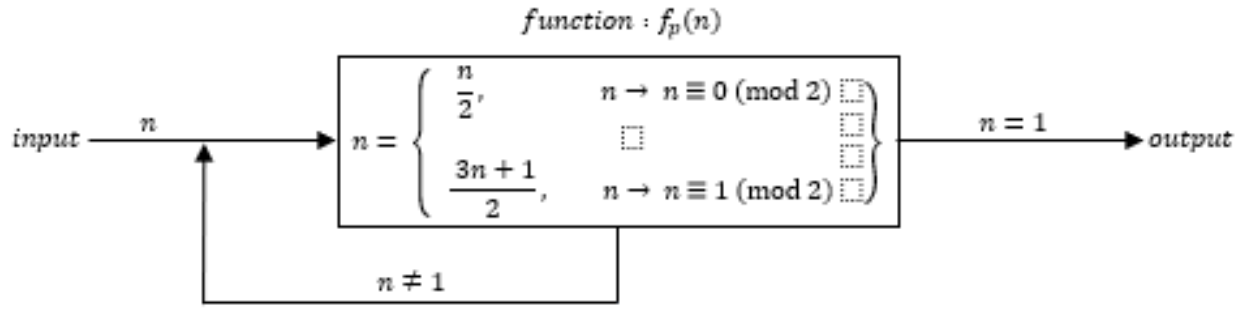

Şekil 3.2. Collatz Konjektürü parite sekans yöntemi fonksiyon gösterimi.

Akış şeması, iş akışını veya süreci temsil eden bir diyagram türüdür. İşlemi gerçekleştirmek için gereken adımların ve süreci ifade eden algoritmanın görsel veya sembolik bir temsilidir. Akış şeması sürecin baştan sona mantıksal olarak izlenmesine olanak tanır. Collatz Konjektürü’de parite sekansı yöntemi ile işlemlerini yapacak olan programın algoritması aşağıdaki şekilde geliştirilmiştir;

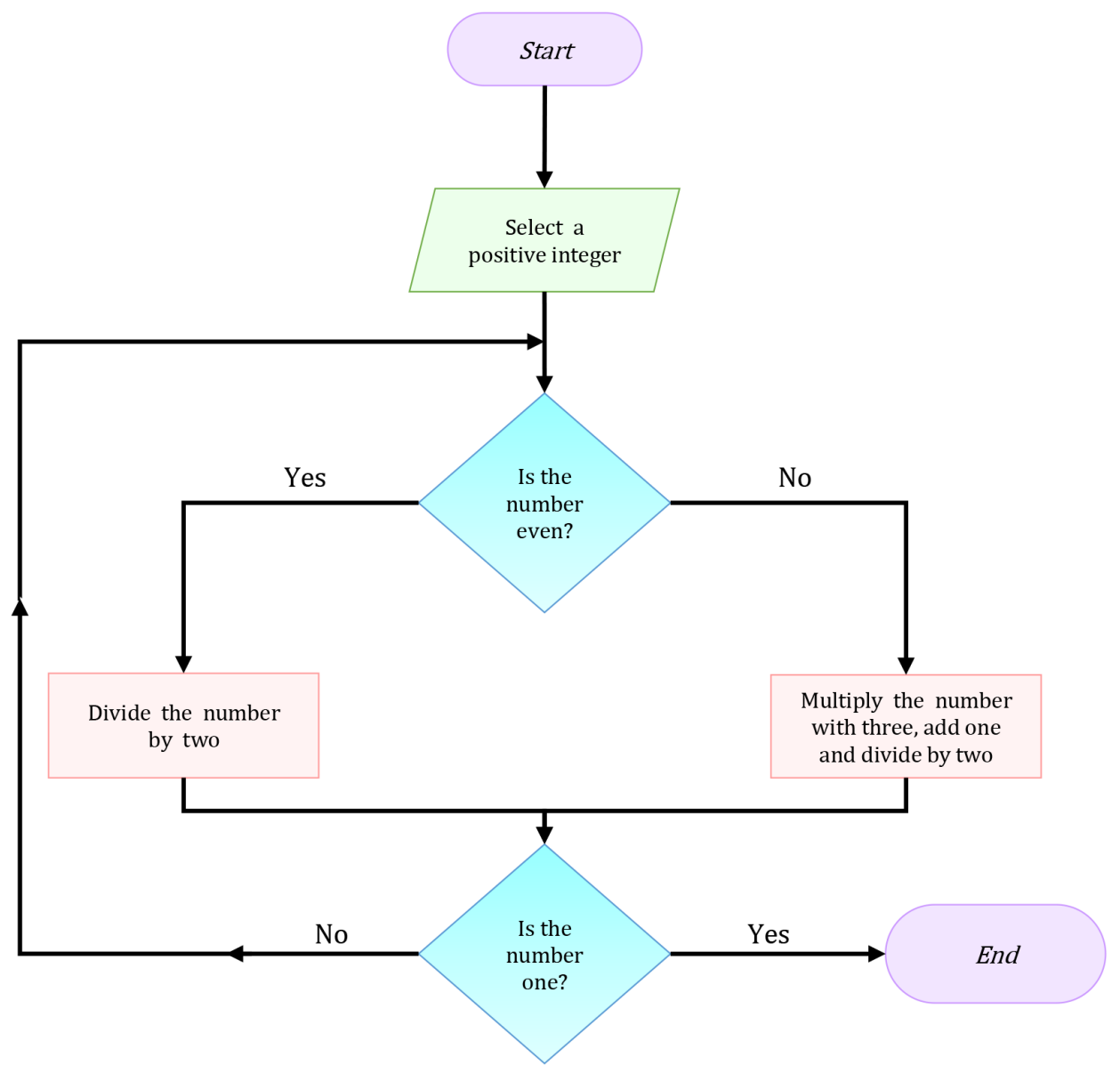

Şekil 3.3. Collatz Konjektürü parite sekansı yöntemi akış diyagramı. 


\subsubsection{Program kodu}

Collatz Konjektürü’nde parite sekansı yöntemi işlemlerinin bilgisayarda yapılabilmesi için bilgisayar programı geliştirilmiştir. Program parite sekansı yöntemine yönelik yani Collatz Konjektürü’nün türetilmiş tanımı ve türetilmiş fonksiyonu üzerinden kurgulanmıştır.

Bilgisayar programı istenilen sayı aralığında hesaplama işlemleri yapıp, başlangıç değerleri, işlem yapılan seriler ve toplam adım sayılarından oluşan bir sonuç listesi üretebilecek şekilde tasarlanmıştır. Bu çalışma mekanizmasında algoritma daha gelişmiş hale getirilmiştir. Program kodu aşağıda paylaşılmıştır;

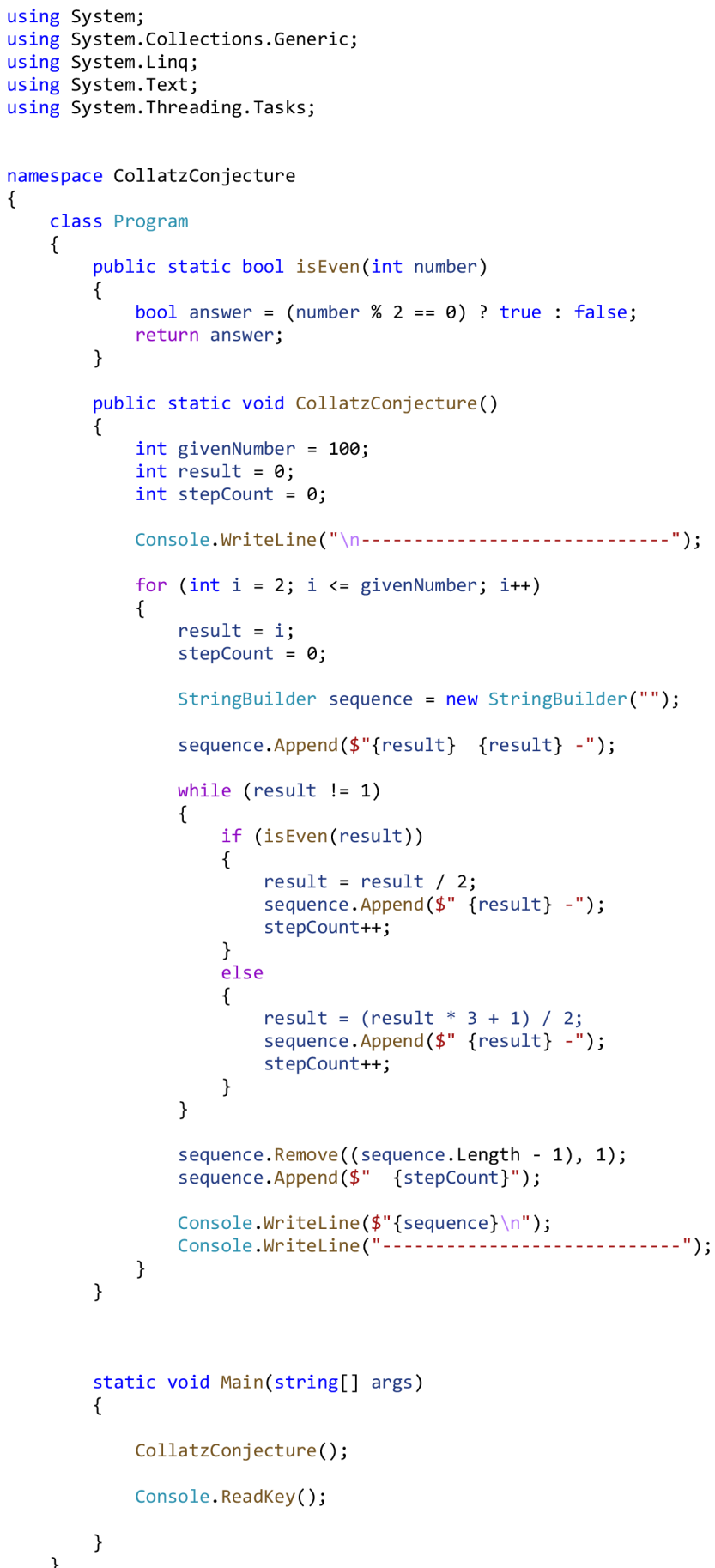




\subsubsection{Sonuçlar}

\subsubsection{Program çıktısı}

Collatz Konjektürü’nde parite sekansı yöntemi işlemlerinin bilgisayarda yapılabilmesi için geliştirilen bilgisayar programı çalıştırılmıştır. Program parite sekansı yönteminde hesaplama işlemlerini yapıp, başlangıç değerleri, işlem yapılan seriler ve toplam adım sayılarından oluşan bir sonuç listesi üretmiştir. Sonuçlar öncelikle program çıktısı, daha sonrasında ise sonuç listesinin tam tablosu olarak iki aşamada incelenmiştir.

Program çıktısı aşağıda sunulmaktadır;

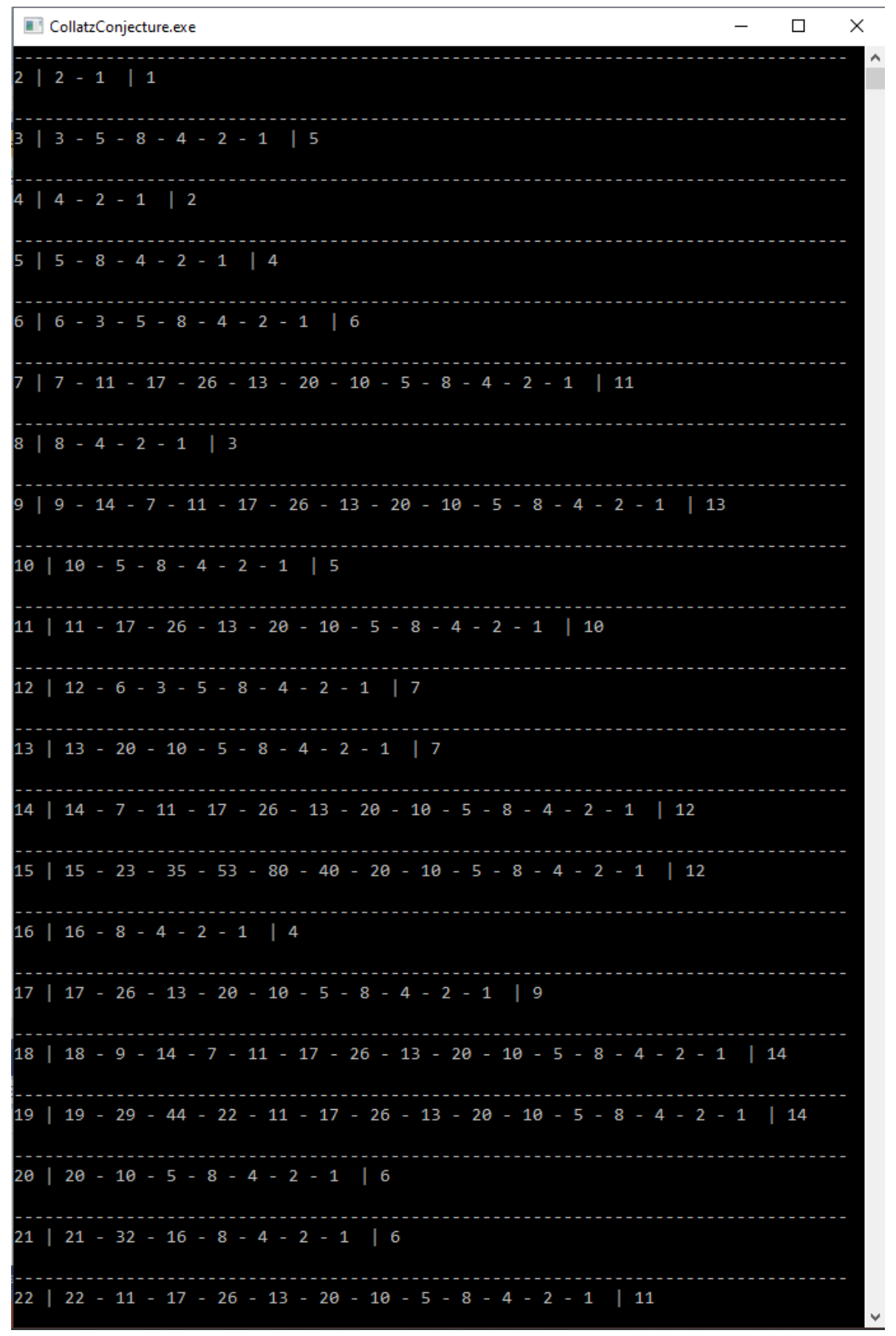

Şekil 3.4. Collatz Konjektürü parite sekansı yöntemi program çıktısı. 
Sonuç listesine ait tam tablo ise aşağıdaki gibidir;

Çizelge 3.1: Parite sekansı yöntemi program çıktısının tablosu.

\begin{tabular}{|c|c|c|}
\hline n & Seri & $\mathbf{i}$ \\
\hline 1 & 1 & - \\
\hline 2 & $2-1$ & 1 \\
\hline 3 & $3-5-8-4-2-1$ & 5 \\
\hline 4 & $4-2-1$ & 2 \\
\hline 5 & $5-8-4-2-1$ & 4 \\
\hline 6 & $6-3-5-8-4-2-1$ & 6 \\
\hline 7 & $7-11-17-26-13-20-10-5-8-4-2-1$ & 11 \\
\hline 8 & $8-4-2-1$ & 3 \\
\hline 9 & $9-14-7-11-17-26-13-20-10-5-8-4-2-1$ & 13 \\
\hline 10 & $10-5-8-4-2-1$ & 5 \\
\hline 11 & $11-17-26-13-20-10-5-8-4-2-1$ & 10 \\
\hline 12 & $12-6-3-5-8-4-2-1$ & 7 \\
\hline 13 & $13-20-10-5-8-4-2-1$ & 7 \\
\hline 14 & $14-7-11-17-26-13-20-10-5-8-4-2-1$ & 12 \\
\hline 15 & $15-23-35-53-80-40-20-10-5-8-4-2-1$ & 12 \\
\hline 16 & $16-8-4-2-1$ & 4 \\
\hline 17 & $17-26-13-20-10-5-8-4-2-1$ & 9 \\
\hline 18 & $18-9-14-7-11-17-26-13-20-10-5-8-4-2-1$ & 14 \\
\hline 19 & $19-29-44-22-11-17-26-13-20-10-5-8-4-2-1$ & 14 \\
\hline 20 & $20-10-5-8-4-2-1$ & 6 \\
\hline 21 & $21-32-16-8-4-2-1$ & 6 \\
\hline 22 & $22-11-17-26-13-20-10-5-8-4-2-1$ & 11 \\
\hline 23 & $23-35-53-80-40-20-10-5-8-4-2-1$ & 11 \\
\hline 24 & $24-12-6-3-5-8-4-2-1$ & 8 \\
\hline 25 & $25-38-19-29-44-22-11-17-26-13-20-10-5-8-4-2-1$ & 16 \\
\hline 26 & $26-13-20-10-5-8-4-2-1$ & 8 \\
\hline 27 & $\begin{array}{l}27-41-62-31-47-71-107-161-242-121-182-91-137-206-103-155-233-350-175-263-395-593-890-445-668 \\
-334-167-251-377-566-283-425-638-319-479-719-1079-1619-2429-3644-1822-911-1367-2051-3077-4616- \\
2308-1154-577-866-433-650-325-488-244-122-61-92-46-23-35-53-80-40-20-10-5-8-4-2-1\end{array}$ & 70 \\
\hline 28 & $28-14-7-11-17-26-13-20-10-5-8-4-2-1$ & 13 \\
\hline 29 & $29-44-22-11-17-26-13-20-10-5-8-4-2-1$ & 13 \\
\hline 30 & $30-15-23-35-53-80-40-20-10-5-8-4-2-1$ & 13 \\
\hline
\end{tabular}

$31-47-71-107-161-242-121-182-91-137-206-103-155-233-350-175-263-395-593-890-445-668-334-167-$

$31251-377-566-283-425-638-319-479-719-1079-1619-2429-3644-1822-911-1367-2051-3077-4616-2308-1154$ $-577-866-433-650-325-488-244-122-61-92-46-23-35-53-80-40-20-10-5-8-4-2-1$

$32 \quad 32-16-8-4-2-1$

$33 \quad 33-50-25-38-19-29-44-22-11-17-26-13-20-10-5-8-4-2-1$

$34 \quad 34-17-26-13-20-10-5-8-4-2-1$

$35 \quad 35-53-80-40-20-10-5-8-4-2-1$

$36 \quad 36-18-9-14-7-11-17-26-13-20-10-5-8-4-2-1$

$37 \quad 37-56-28-14-7-11-17-26-13-20-10-5-8-4-2-1$

$38 \quad 38-19-29-44-22-11-17-26-13-20-10-5-8-4-2-1$

$3939-59-89-134-67-101-152-76-38-19-29-44-22-11-17-26-13-20-10-5-8-4-2-1$

$4040-20-10-5-8-4-2-1$

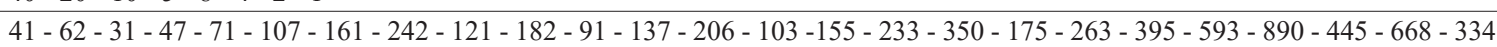

41

- 167 - 251 - 377 - 566 - 283 - 425 - 638 - 319 - 479 - 719 - 1079 - 1619 - 2429 - 3644 - 1822 - 911 - 1367 - 2051 - 3077 - 4616 - 2308 -

$1154-577-866-433-650-325-488-244-122-61-92-46-23-35-53-80-40-20-10-5-8-4-2-1$

$42 \quad 42-21-32-16-8-4-2-1$

$43 \quad 43-65-98-49-74-37-56-28-14-7-11-17-26-13-20-10-5-8-4-2-1$

$44 \quad 44-22-11-17-26-13-20-10-5-8-4-2-1$

$45 \quad 45-68-34-17-26-13-20-10-5-8-4-2-1$

$46 \quad 46-23-35-53-80-40-20-10-5-8-4-2-1$

$47-71$ - 107 - 161 - 242 - 121 - 182 - 91 - 137 - 206 - 103 - 155 - $233-350$ - 175 - 263 - 395 - 593 - 890 - 445 - 668 - 334 - 167 - 251

47

- 377 - $566-283-425-638-319-479-719-1079-1619-2429-3644-1822-911-1367-2051-3077-4616-2308-1154-577$

$-866-433-650-325-488-244-122-61-92-46-23-35-53-80-40-20-10-5-8-4-2-1$

$48 \quad 48-24-12-6-3-5-8-4-2-1$

$4949-74-37-56-28-14-7-11-17-26-13-20-10-5-8-4-2-1$ 


\begin{tabular}{|c|c|c|}
\hline 50 & $50-25-38-19-29-44-22-11-17-26-13-20-10-5-8-4-2-1$ & 17 \\
\hline 51 & $51-77-116-58-29-44-22-11-17-26-13-20-10-5-8-4-2-1$ & 17 \\
\hline 52 & $52-26-13-20-10-5-8-4-2-1$ & 9 \\
\hline 53 & $53-80-40-20-10-5-8-4-2-1$ & 9 \\
\hline 54 & $\begin{array}{l}54-27-41-62-31-47-71-107-161-242-121-182-91-137-206-103-155-233-350-175-263-395-593-890-445- \\
668-334-167-251-377-566-283-425-638-319-479-719-1079-1619-2429-3644-1822-911-1367-2051-3077-4616 \\
-2308-1154-577-866-433-650-325-488-244-122-61-92-46-23-35-53-80-40-20-10-5-8-4-2-1\end{array}$ & 71 \\
\hline 55 & $\begin{array}{l}55-83-125-188-94-47-71-107-161-242-121-182-91-137-206-103-155-233-350-175-263-395-593-890-445 \\
-668-334-167-251-377-566-283-425-638-319-479-719-1079-1619-2429-3644-1822-911-1367-2051-3077- \\
4616-2308-1154-577-866-433-650-325-488-244-122-61-92-46-23-35-53-80-40-20-10-5-8-4-2-1\end{array}$ & 71 \\
\hline 56 & $56-28-14-7-11-17-26-13-20-10-5-8-4-2-1$ & 14 \\
\hline 57 & $57-86-43-65-98-49-74-37-56-28-14-7-11-17-26-13-20-10-5-8-4-2-1$ & 22 \\
\hline 58 & $58-29-44-22-11-17-26-13-20-10-5-8-4-2-1$ & 14 \\
\hline 59 & $59-89-134-67-101-152-76-38-19-29-44-22-11-17-26-13-20-10-5-8-4-2-1$ & 22 \\
\hline 60 & $60-30-15-23-35-53-80-40-20-10-5-8-4-2-1$ & 14 \\
\hline 61 & $61-92-46-23-35-53-80-40-20-10-5-8-4-2-1$ & 14 \\
\hline 62 & $\begin{array}{l}62-31-47-71-107-161-242-121-182-91-137-206-103-155-233-350-175-263-395-593-890-445-668-334-167 \\
-251-377-566-283-425-638-319-479-719-1079-1619-2429-3644-1822-911-1367-2051-3077-4616-2308-1154 \\
-577-866-433-650-325-488-244-122-61-92-46-23-35-53-80-40-20-10-5-8-4-2-1\end{array}$ & 68 \\
\hline 63 & $\begin{array}{l}63-95-143-215-323-485-728-364-182-91-137-206-103-155-233-350-175-263-395-593-890-445-668-334 \\
-167-251-377-566-283-425-638-319-479-719-1079-1619-2429-3644-1822-911-1367-2051-3077-4616-2308- \\
1154-577-866-433-650-325-488-244-122-61-92-46-23-35-53-80-40-20-10-5-8-4-2-1\end{array}$ & 68 \\
\hline 64 & $64-32-16-8-4-2-1$ & 6 \\
\hline 65 & $65-98-49-74-37-56-28-14-7-11-17-26-13-20-10-5-8-4-2-1$ & 19 \\
\hline 66 & $66-33-50-25-38-19-29-44-22-11-17-26-13-20-10-5-8-4-2-1$ & 19 \\
\hline
\end{tabular}

\subsubsection{Program grafikleri}

Collatz Konjektürü parite sekansı yönteminde hesaplama işlemlerini yapan bilgisayar programına ait tüm detaylar önceki bölümlerde incelenmiştir. Bu program haricinde yine parite sekansı yönteminde yapılan bu işlemlerin grafiklerini oluşturan bir bilgisayar programı daha geliştirilmiştir. Programda sayıların adım sayılarına göre oluşturulmuş sütun grafiği, sp çizgi grafiği, çizgi grafiği ve polar grafik geliştirmeleri yapılmıştır.

Geliştirilen program grafikleri aşağıda grafik bazında yer almaktadır; 


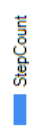

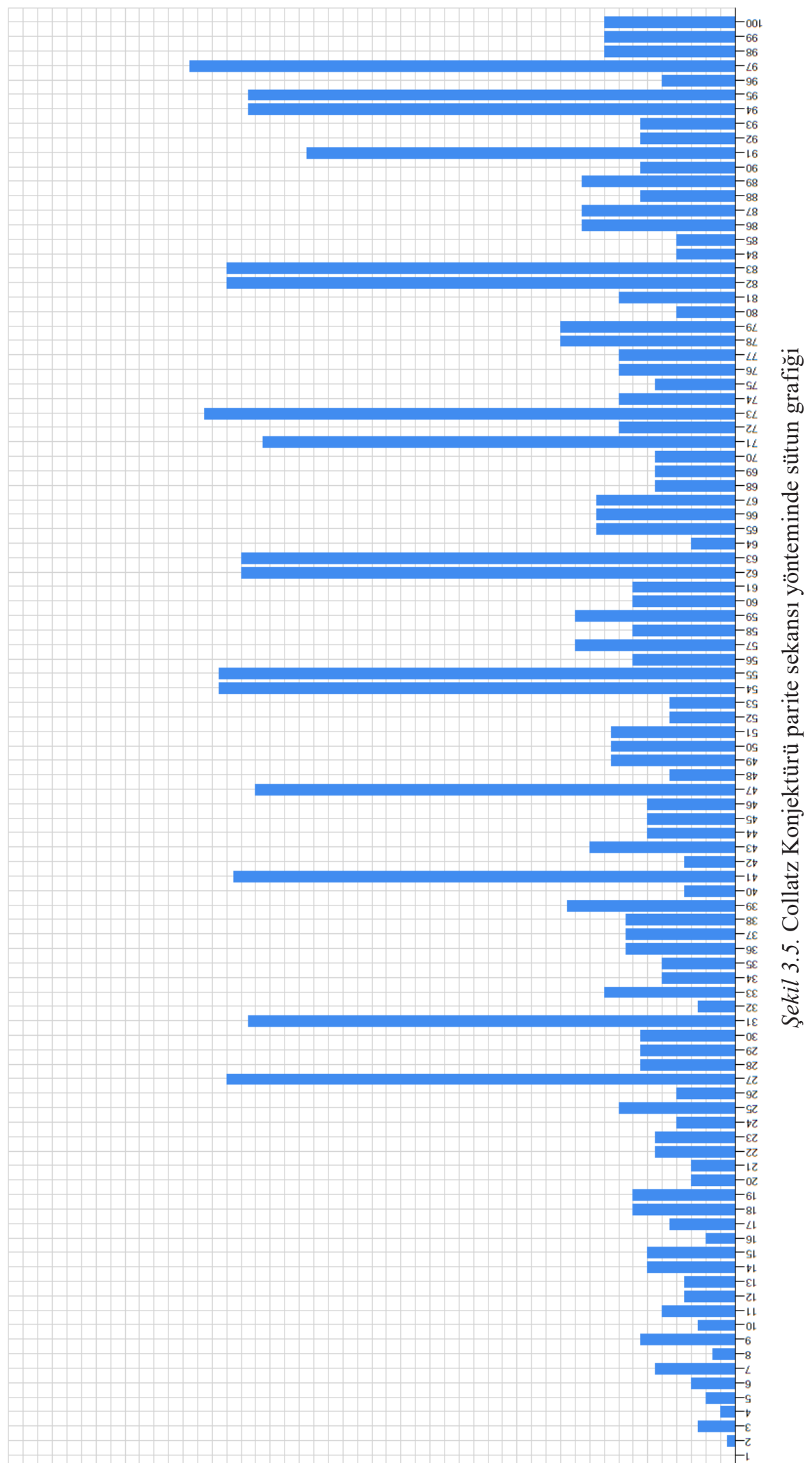

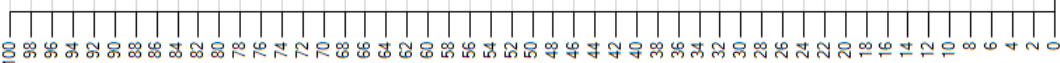




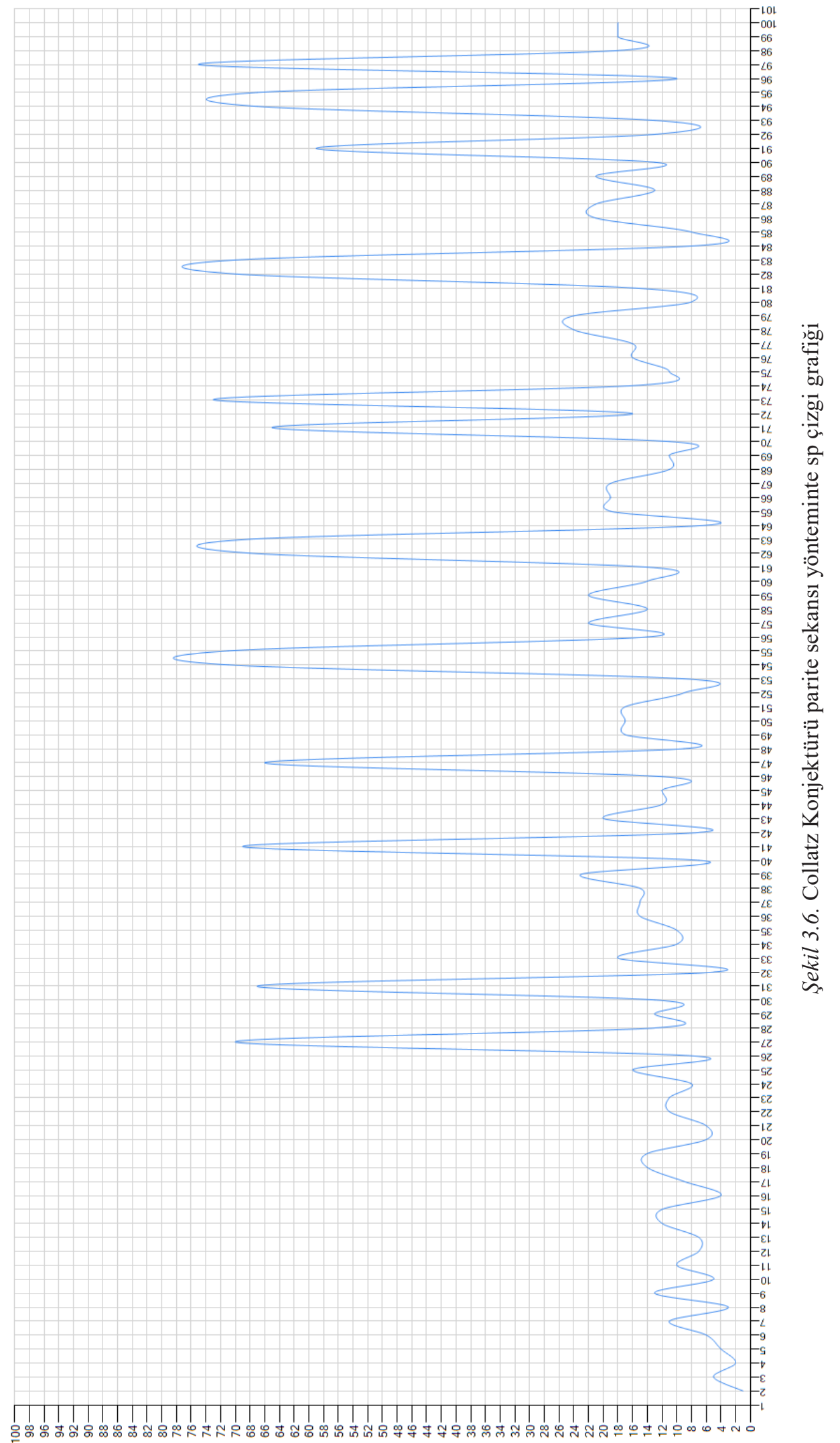




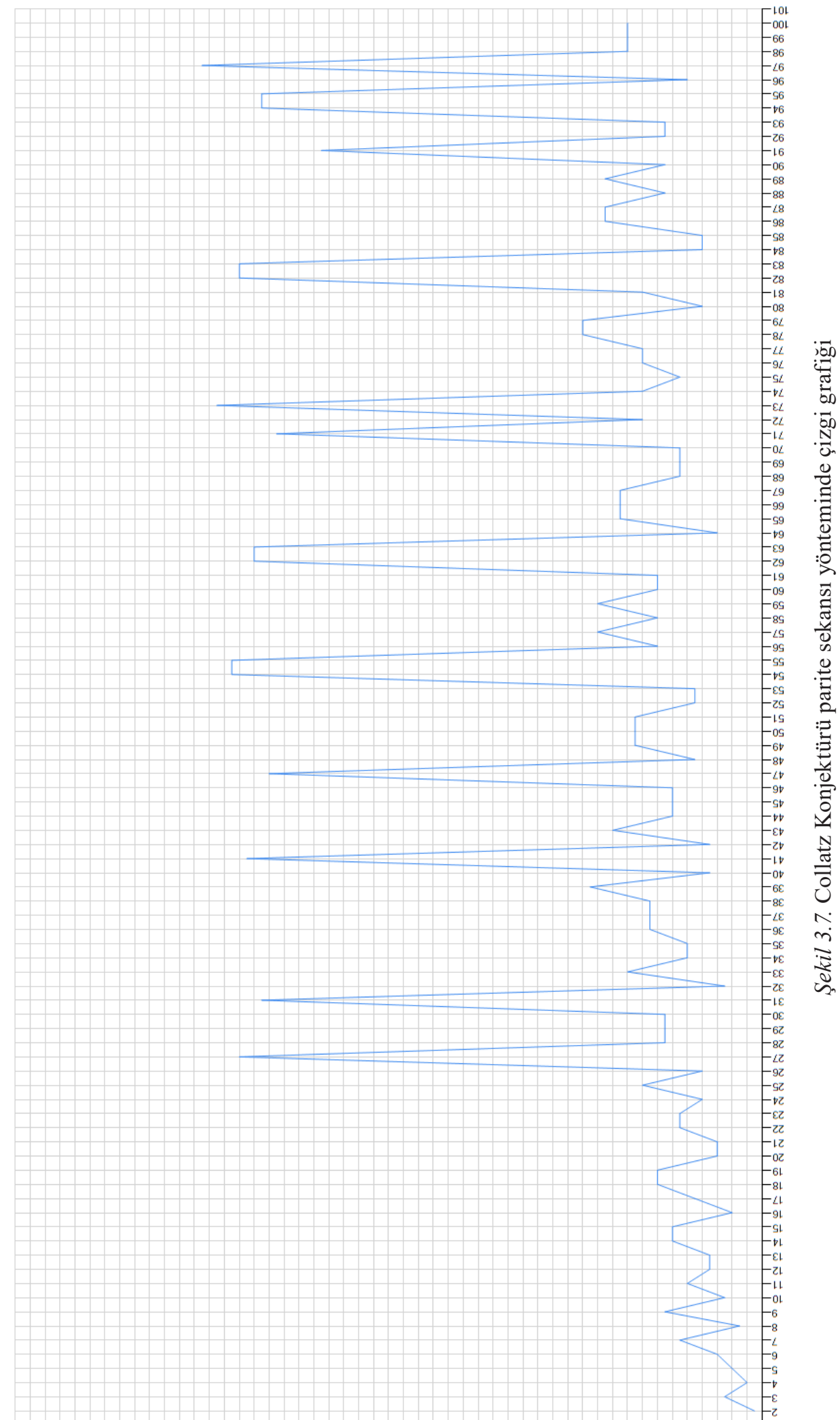

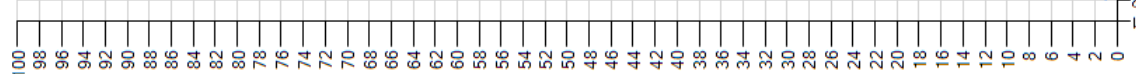




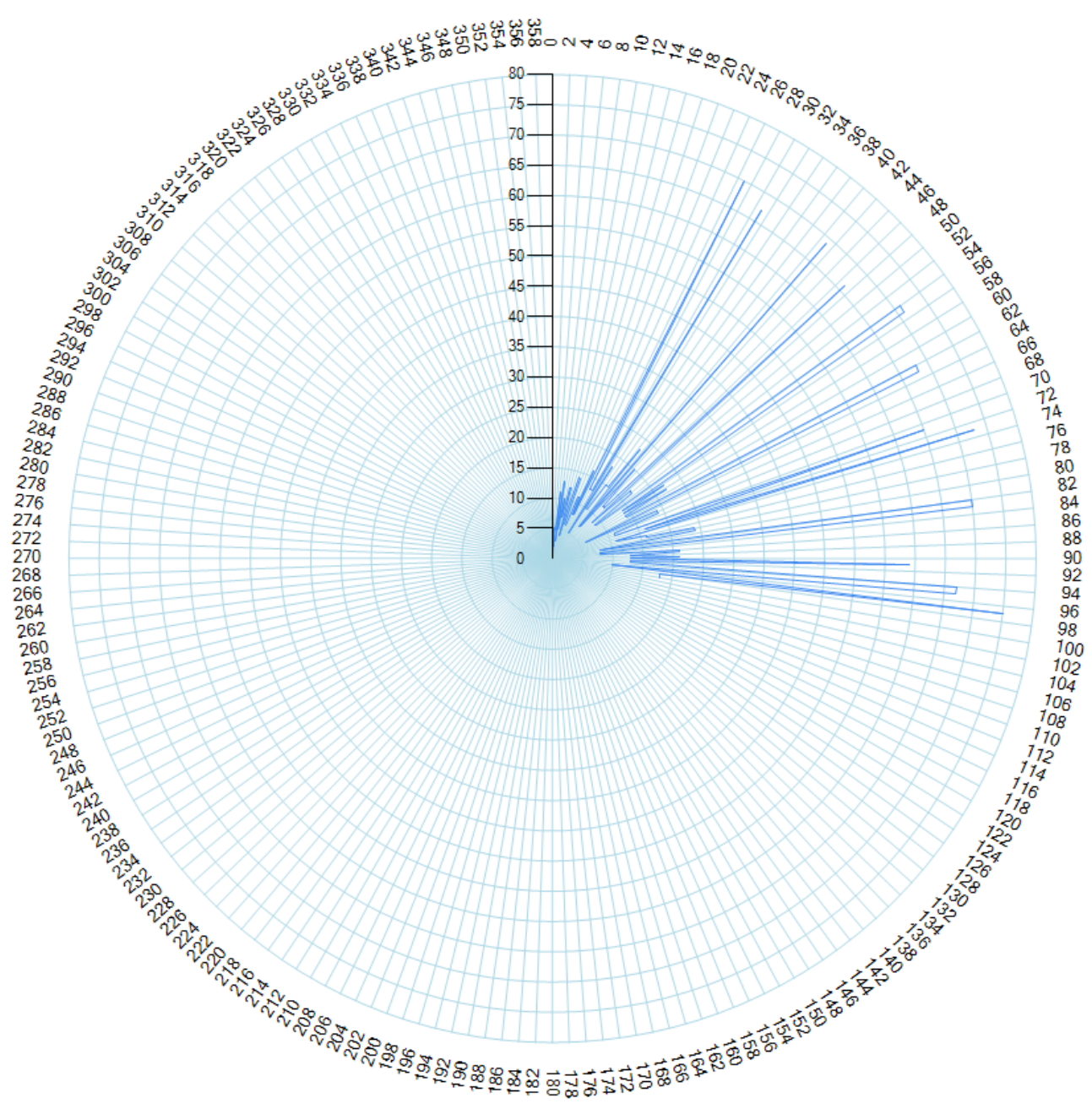

\subsubsection{Grafiksel gösterim program kodu}

Collatz Konjektürü parite sekansı yönteminde yapılan hesaplama işlemlerinin grafiklerini oluşturan bilgisayar programı çıktıları incelenmiştir. Programda sayıların adım sayılarına göre oluşturulmuş sütun grafiği, sp çizgi grafiği, çizgi grafiği ve polar grafikleri oluşturulmuştur. Bu grafiklerin üretildiği program kodu aşağıda paylaşılmıştır;

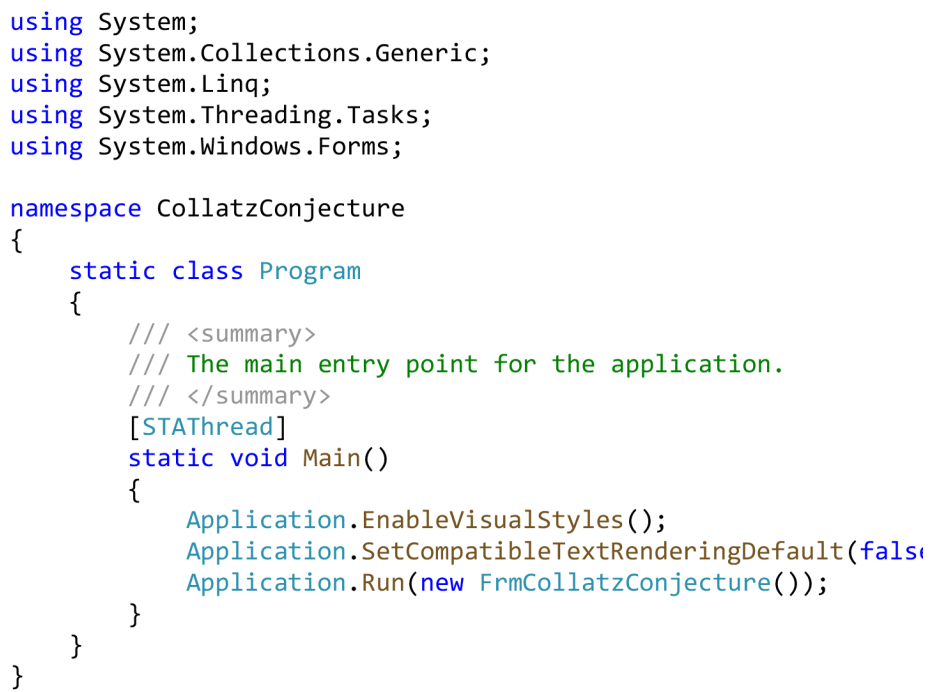




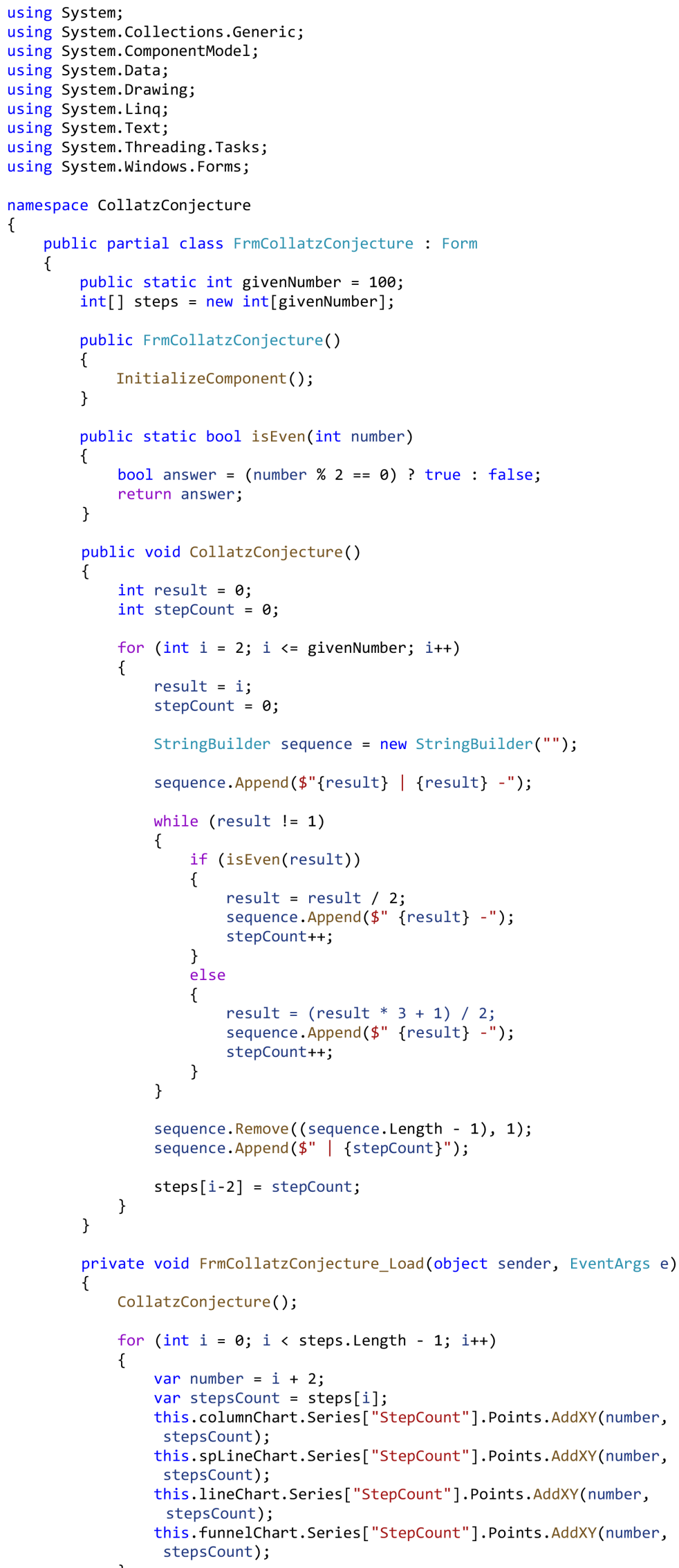




\section{SONUÇ VE ÖNERİLER}

Bilgisayarlar günümüz dünyasının ilerleyişinde gelinen noktada ve gelecekle ilgili yapılan çalışmalarda önemli bir rol oynamaktadır. Son derece hızlı olmaları ,yüksek işlem kapasiteleri, düşük hata oranları bu konuda pay sahibidir. İnternet kullanımının dünya genelinde yaygınlaşması da bilgisayarların insan yaşantısında bir yer edinmesine ivme kazandırmıştır. Bilgisayar hayatın her alanında olduğu gibi bilim ve mühendislik alanlarında da etkisini göstermektedir.

Collatz Konjektürü sadece matematiksel ve bilimsel bir çalışma konusu olmanın ötesindedir. Bilgisayar Mühendisliği ve Bilgisayar Bilimleri açısından bu tip bilimsel çalışmalarda önemli bir ortak olmanın yanı sıra, konjektür algoritmasının işlemlerde yararlanıldığı çeşitli uygulama alanları bulunmaktadır. Steganografi, kriptoloji, veri gizleme ve filigranlama alanlarında da Collatz Konjektürü algoritmasının kullanıldığı çalışmalar yer almaktadır (Tuncer \& Kurum, 2020).

Makalenin ikinci bölümünde; Collatz Konjektürü’nün çıkış noktası, problemin tanımı, fonksiyonu ve matematiksel notasyonda gösterimine istinaden açıklamaları bulunmaktadır. Ayrıca Collatz Konjektürü senaryo ve realizasyonları, bilinen iterasyonları, görselleri ve günümüzde geldiği son noktadaki güncel bilgilere de yer verilmiştir.

Makalenin üçüncü bölümünde; Collatz Konjektürü işlemlerinin yapılabilmesi için geliştirilen bilgisayar programları yer almaktadır. Parite sekansı yöntemi üzerinde oldukça detaylı bir şekilde çalışılmış ve bir yöntem önerisinde bulunulmuştur. Yöntem özelinde metodoloji oluşturulmuş, önerme, prosedür ve notasyon çalışmaları yapılmıştır. Bilgisayar programları mimarisi ile açıklanmış, algoritma ve akış diyagramları geliştirilmiştir. Bilgisayar programlarının yanı sıra, program kodları, program çıktıları, çıktılardan oluşturulan tablolar paylaşılmış ve grafikler ile zenginleştirilmiştir.

Collatz Konjektürü’nün hesaplanması için “Parite Sekansı Yöntemi” önerilmektedir. Önerilen yöntem standart yöntem ile karşılaştırılmıştır. 1 ve 100 arasındaki sayılar için ölçüm yapılmıştır. Standart yöntemde toplamda 3142 adımda 1 rakamına ulaşılabilirken, parite sekansı yönteminde ise toplamda 2137 adımda 1 rakamına ulaşılabilmektedir. Aradaki toplam adım sayısı farkı 1005 olarak hesaplanmıştır. Yine standart yöntemde tüm işlemlerin tamamlanması 100 milisaniye yani 0.1 saniye sürerken, parite sekansı yönteminde ise tüm işlemlerin yapılması 84 milisaniye yani 0.084 saniye sürmektedir. Aradaki toplam tamamlanma süresi fark1 16 milisaniye yani 0.016 saniye olarak hesaplanmıştır. Parite sekansı yönteminde standart yöntemin yaklaşık \%68.01'i kadar işlem adımında 1 rakamına ulaşılabilmektedir. Yani yaklaşık \%31.99 oranında daha az toplam adım sayısı ile 1 rakamına ulaşılabilmektedir. Yine parite sekansı yönteminde standart yönteme göre tüm işlemlerin tamamlanması \%84 oranı süresinde, yani \%16 oranında daha kısa sürede ölçülmüştür.

Hakem Değerlendirmesi: Dış bağımsız.

Çıkar Çatışması: Yazarlar çıkar çatışması bildirmemiştir.

Finansal Destek: Yazarlar bu çalışma için finansal destek almadığını beyan etmiştir.

Peer-review: Externally peer-reviewed.

Conflict of Interest: The authors have no conflict of interest to declare.

Grant Support: The authors declared that this study has received no financial support.

\section{Kaynaklar/References}

Guenther, R. B. , 1992, “Lothar Collatz, 1910-1990”. https://link.springer.com/article/10.1007/BF01840490 (04.03.2020).

O’Connor, J. J., Robertson, E. F. , 2006, “Lothar Collatz”. https://mathshistory.st-andrews.ac.uk/Biographies/Collatz/ (04.03.2020).

Hammett, M. , t.y. , "The Collatz Conjecture: A Brief Overview”. http://online.sfsu.edu/meredith/301/Papers/FinalDraft_Hammett.pdf (04.03.2020).

Lagarias, J. C. , 2011, “The 3x+1 Problem: An Annotated Bibliography,1963-1999”. https://arxiv.org/pdf/math/0309224.pdf (04.03.2020).

Deloin, R., 2019. "Proof of Collatz Conjecture”. https://www.journalarjom.com/index.php/ARJOM/article/view/30123/56520 (04.03.2020).

Phillips, A. J. , 2010. “Parity Periodicity: An Eliminative Approach to the Collatz Conjecture". https://scholarlycommons.obu.edu/honors_theses/53/ (04.03.2020).

Davies, J. , 2012. “Collatz Graph: All Numbers Lead to One”. https://www.jasondavies.com/collatz-graph/ (04.03.2020).

Barina, D. , 2020. “Convergence Verification of the Collatz Problem”. https://link.springer.com/article/10.1007/s11227020-03368-x (04.03.2020). 
Honner, P. , 2020. “The Simple Math Problem We Still Can’t Solve”. https://www.quantamagazine.org/why-mathematicians-still-cant-solve-the-collatzconjecture-20200922/ (04.03.2020).

Santos, O. D. O. , 2018. "Proving the Collatz Conjecture with Binaries Numbers". article.sciencepublishinggroup.com (04.03.2020).

t.y. "Cliff Pickover's Patterns in the Mysterious Hailstone ,3n+1 Numbers". http://sprott.physics.wisc.edu/pickover/hailstone.html (04.03.2020).

t.y. “3x+1 Delay Records". http://www.ericr.nl/wondrous/delrecs.html (04.03.2020).

Haran, B. , 2017. “The Collatz Conjecture in Colour”. https://www.bradyharanblog.com/blog/the-collatz-conjecture-in-colour (04.03.2020).

Tao, T. , 2019. “Almost All Orbits Of The Collatz Map Attain Almost Bounded Values”. https://arxiv.org/abs/1909.03562 (04.03.2020).

Tuncer, T. , Kurum, H. Y. , 2020. “A Novel Collatz Conjecture-Based Digital İmage Watermarking Method”. https://www.tandfonline.com/doi/ abs/10.1080/01611194.2020.1821408?journalCode=ucry20 (04.03.2020).

2020. “Compute for Science". https://boinc.berkeley.edu/ (04.03.2020).

Sonntag J. , 2020. "What is Collatz Conjecture?” https://boinc.thesonntags.com/collatz/ (04.03.2020).

2020. “Collatz Best Results”. https://boinc.thesonntags.com/collatz/highest_steps.php (04.03.2020).

2020. “Today’s High Steps”. https://boinc.thesonntags.com/collatz/high_steppers.php (04.03.2020).

Weisstein. E. W. , t.y. "Collatz Problem”. https://mathworld.wolfram.com/CollatzProblem.html (04.03.2020).

Bairrington, B., Okano, A., 2019. "New Experimental Investigations for the 3x+1 Problem: The Binary Projection of the Collatz Map". https:/scholar. rose-hulman.edu/cgi/viewcontent.cgi?article=1393\& context $=$ rhumj (04.03.2020). 
